\title{
CORINE Sistemine Göre Kars İlinde Arazi Örtüsü/Arazi Kullanımı, Değişimi ve Projeksiyonu
}

\section{Land Cover/Land Use, Change, and Projection in the Kars Province according to the CORINE System}

\section{Mucip DEMIR ${ }^{1} \oplus$}

${ }^{1}$ Doç. Dr. Kafkas Üniversitesi, Dede Korkut Eğitim Fakültesi Sosyal Bilimler ve Türkçe Eğitimi Bölümü, Coğrafya Öğretmenliği Anabilim Dalı, Kars, Türkiye

ORCID: M.D. 0000-0003-1122-2664

\section{ÖZ}

Bu çalışmada CORINE sistemine göre Kars ilinde arazi örtüsü/arazi kullanımında periyodik olarak meydana gelen değişimin tespit edilmesi, bu değişime etki eden doğal ve beşeri çevre faktörlerinin belirlenmesi ve gelecekteki arazi kullanımının projeksiyone edilmesi amaçlanmıştır.

Araştırmada Kars ili idari sınırlarına göre özelleştirilmiş CORINE sistemindeki ilk örneklem yılını temsil eden 1990 yılı vektör verileri ile aynı sistemin son örneklem yılını temsil eden 2018 yılına ait vektör verileri kullanılmıştır. Bu veri setleri üzerinde yapılan analizlerde araştırma örneklemini oluşturan her iki yılda da İlde 5 ana arazi örtüsü/arazi kullanımı sınıfına ait 23 arazi alt sınıfı tespit edilmiştir. Örneklem yılları karşılaştırmasında İlde arazi örtüsü/arazi kullanımında anlamlı düzeyde değişimin meydana geldiği tespit edilmiş olup bu değişimin büyük oranda ildeki tarım ve hayvancılık faaliyetlerine bağlı olarak meydana geldiği anlaşılmıştır.

Araştırmanın son aşamasında üzerinde Çok Katmanlı Algılayıcı (MLP), Yapay Sinir Ağı (YSA) ve Markov zinciri (MC) yaklaşımlarını birleștiren hibrit bir modelle İldeki arazi örtüsü/arazi kullanımının 2040 yılındaki durumu projeksiyone edilmiştir. Buna göre araştırma örneklemini oluşturan yıllardaki duruma paralel olarak 2040 yılında İldeki arazi örtüsü/arazi kullanımının anlamlı düzeyde değişiklik gösterebileceği sonucu ortaya çıkmıştır.

Anahtar kelimeler: Kars, Arazi Örtüsü, Arazi Kullanımı, CORINE

\section{ABSTRACT}

This study aims to determine the changes that occur periodically in the land cover/land use in the Kars province according to the coordination of information on the environment (CORINE) system, to determine the natural and human environmental factors that affect this change and help project future land use. In the study, a 1990 vector data set representing the first sampling year in the CORINE system and customized according to the administrative boundaries of the Kars province and a vector data set of 2018 representing the last sampling year of the same system were used. In the analysis made on these data sets, 23 land subclasses belonging to five mainland cover/land use class in the province were determined in both years that constitute the research sample. In the last stage of the research, the situation of land cover/land use in the province in 2040 was projected with a hybrid model combining multilayer perceptron, artificial neural network, and Markov chain (MC) approaches. Accordingly, in parallel with the situation in the years constituting the research sample, it was concluded that the land cover/land use in the province could significantly change in 2040.

Keywords: Kars, Land Cover, Land Use, CORINE

Başvuru/Submitted: 27.02.2021 • Revizyon Talebi/Revision Requested: 31.03.2021 • Son Revizyon/Last Revision Received: 09.06 .2021 • Kabul/Accepted: $25.10 .2021 \cdot$ Online Yayın/Published Online: 00.00 .0000

Sorumlu yazar/Corresponding author: Mucip DEMiR / mucipdemir@hotmail.com

Atıf/Citation: Demir, M. (2021). CORINE sistemine göre Kars ilinde arazi örtüsü/arazi kullanımı, değişimi ve projeksiyonu. Cografya Dergisi, 43, 93-110. https://doi.org/10.26650/JGEOG2021-887753 


\section{EXTENDED ABSTRACT}

Kars Province, which constitutes the research area, is located in Northeast Anatolia. Kars Province; It is surrounded by Ardahan in the north, Shirak administrative division of Armenia in the east, Iğdır in the southeast, Ağrı in the south and Erzurum in the west.In the province of Kars, there are 8 districts, namely Merkez, Sarıkamış, Kağızman, Selim, Susuz, Arpaçay, Akyaka and Digor, and 383 villages and 55 neighborhood settlements connected to these districts, with a total surface area of 10,196 $\mathrm{km}^{2}$.

According to the analysis made using the CORINE 1990 and 2018 data sets, there are lands belonging to 23 land subclasses in 5 mainland cover/land use class in Kars, which has an area of 10,196 km². According to CORINE data, $160 \mathrm{~km}^{2}$, which constitutes $2 \%$ of the land of the Kars province, is in the general class of Artificial Surfaces with "1" main code where almost all of the human economic activities are performed.

While most of the lands in the general class of Artificial Surfaces with the main code "1" in Kars are in the Merkez district, which is the administrative and commercial center of the province and its surroundings, the remaining part is concentrated in the district centers of Sarıkamış and Kağızman, which show urban characteristics.

Most of the lands in the "2" main code Agricultural Areas general class in the province are gathered in the Central District and its surroundings on the Kars plateau and spread over an area of $5,984 \mathrm{~km}^{2}$, which corresponds to $58.7 \%$ of the general area of the province.

Most of the lands in the "3" main code Forest and Semi-Natural Areas class in the province were collected along the Allahuekber mountains surrounding the provincial administrative area from the west, the Aras Güneyi mountains surrounding the south, and the Aras Valley, where the altitude and slope values severely restrict the population and settlement. The lands included in this main class in the province have a surface area of $3,946 \mathrm{~km}^{2}$, which corresponds to $38.7 \%$ of the province.

Most of the lands in the "Wet Surface Areas general class" with the main code of " 4 " in Kars are located in the coastal areas of Ç1ldır lake, Kuyucuk lake, Arpaçay dam lake, and Aras river. These lands are partially reed swampy. All wet swamp lands in the province have an area of $17.0 \mathrm{~km}^{2}$, which constitutes $0.16 \%$ of the province's land area.

Lands in the general class of Water Communities with the main code " 5 " in the Kars province have a surface area of $89 \mathrm{~km}^{2}$, which corresponds to $0.9 \%$ of the total land in the province. While most of the lands in the subclass of Waterways subclass of 511 streams, streams and streams within this main land class are Aras River and Arpaçay rivers, most of the lands in the "512" sub-code water bodies class in the Çıldır, Aygır, and Kuyucuk lakes, and Arpaçay dam lake are available.

According to the comparison made and the change matrix created using the 1990 and 2018 CORINE data of the Kars province, land cover/land use change occurred in an area of $1,310 \mathrm{~km}^{2}$, which corresponds to $12.84 \%$ of the provincial area of $10,196 \mathrm{~km}^{2}$. Most of the land cover/land use change in the province occurred due to humanitarian reasons, despite the population decrease in the province. An area of $63.1 \mathrm{~km}^{2}$, which corresponds to $4.8 \%$ of the land cover/land use change in the province, is in the Artificial Surfaces class with the main code "1"; and $586.4 \mathrm{~km}^{2}$ corresponds to $44.7 \%$ is Agriculture with the main code "2." In the Class of Areas, $649.9 \mathrm{~km}^{2}$ corresponds to $49.6 \%$ of the " 3 " main code Forest and Semi-Natural Areas class, and $0.8 \mathrm{~km}^{2}$ corresponds to $0.01 \%$ of Wet Areas with the " 4 " main code. In the class, $10.6 \mathrm{~km}^{2}$ corresponds to $0.1 \%$ occurred in Water Communities with the main code " 5 ."

Based on the data of the years 1990 and 2018, to project the situation of land use in Kars in 2040, analyses were made using the Markov method. It is understood that if the conditions affecting the changes in the land cover and land use in the evaluation range of 1990-2018 in Kars are similar, the projected land cover and land use in the projected 2040 year may change by a total of $1,029 \mathrm{~km}^{2}$ compared to the last sample year, 2018. In the Kars province in 2040, the land cover is projected as $2.1 \%$, in the Artificial Surfaces class, $60.9 \%$, in the Agricultural Lands class, 35.9\% and in the Forest and Semi-Natural Areas class, $0 \%$. It is further projected that 16 of them may consist of the wet area class and $0.9 \%$ of the land in the class of Water Communities. 


\section{GİRIŞ}

Arazi örtüsü daha çok doğal çevre özelliklerine dayalı olarak oluşmuş çıplak kayalık, toprak, bitki örtüsü ve su yüzeylerini kaplayan ve değişebilir yüzey peyzajı olarak tanımlanmaktadır (Comber, vd., 2005). Arazi kullanımı ise bu yüzey peyzajı üzerinde tarım, yerleşme, rekreasyon, madencilik gibi daha çok beşeri faaliyetlerle ve belirli amaçlara dayalı olarak meydana getirilen değişiklikleri ifade etmektedir (Comber, vd., 2005). Arazi örtüsünü oluşturan unsurların dağılımının ve birbirileriyle olan ilişki ve etkileşimlerinin incelenmesi, sürdürülebilir kaynak yönetimi, arazi kullanımı ve planlaması için temel altlık bilgileri sağlayıp aynı zamanda arazi kullanımında uyulması gereken temel yolu ve çerçeveyi de belirler. Arazi kullanımı çalışmaları ise mevcut arazi durumunun belirlenmesi yanında strateji geliştirme ve planlanma bakımından önemli bir yere sahiptir (Fisher, vd., 2005).

Dünya nüfusunda meydana gelen hızlı artış trendine bağlı olarak insani ihtiyaçlar her geçen gün çeşitlenip artış göstermektedir. $\mathrm{Bu}$ nedenle bu ihtiyaçların karşılanmasında başlıca kaynağı oluşturan arazi örtüsü ve arazi kullanımının belirlenmesi sürdürülebilirlik kapsamındaki stratejilerle planlanması ve yönetilmesinin önemi giderek daha da artmaktadır (Turner, vd., 1994). Bu nedenle dünya genelinde birçok ülke ve kuruluş bu amaca yönelik olarak bilimsel araştırmalar yaptırmaktadır (Çivi, vd., 2009). Bu araştırma ve çalışmalardan en önemlilerinden biri Avrupa Birliği ülkelerindeki hava, su, toprak gibi temel çevre unsurlarının bütüncül ve standardize bir şekilde inceleyerek çevre yönetimine yönelik ortak kararlar almak amacıyla 1985 yılında faaliyete geçirilen CORINE çevre bilgi koordinasyonu sistemidir (European Environment Agency. 2020). Bu proje kapsamında Avrupa Birliği ve çevre alanlardaki ülkelerde arazi örtüsü ve arazi kullanımında meydana gelen değişimlerin incelenmesi için de 1990 yılında ilk örnekleri yayınlanan uzaktan algılama ve uydu görüntülerine dayalı bir izleme sistemi oluşturulmuştur (European Environment Agency. 2020).

Avrupa Birliğine 1967 yılından beri aday üye ülke durumunda bulunan Türkiye de Avrupa Birliğine uyum kapsamında 1998 yılından itibaren CORINE sistemi kapsamındaki çalışmalara dâhil olmuştur (Tarım ve Orman Bakanlığı, 2020). Bu amaçla Türkiye de başta, Çevre, Tarım Bakanlıkları ve üniversiteler de bu sistemdeki arazi örtüsü ve arazi kullanımına dair proje ve araştırmalar yapılmaya başlanmıştır. Bu araştırma ve projelerden çıkan sonuçlar Avrupa Birliği çevre politikalarına uygun olarak çevre politikaları ve uygulamalarının hayata geçirilmesinde kullanılmaktadır.

\section{ARAŞTIRMA ALANININ KONUMU, SINIRLARI VE BAŞLICA ÖZELLIKKLERİ}

Araştırma alanını oluşturan Kars ili, Kuzeydoğu Anadolu'da Erzurum Kars Bölümünün, Kars yöresi dâhilinde yer almaktadır. İl; kuzeyde Ardahan, doğuda Ermenistan'ın Shirak yönetim bölümü, güneydoğuda Iğdır, güneyde Ağrı, batıda ise Erzurum İleri idari alanları arasında $10.196 \mathrm{~km}^{2}$ yüz ölçüme sahiptir (HGK, 2014). İl; Merkez, Sarıkamış, Kağızman, Selim, Susuz, Arpaçay, Akyaka ve Digor olmak üzere 8 ilçeye sahip olup bu ilçelere bağlı 383 köy ve 55 mahalle yerleşimi bulunmaktadır (Demir, 2013), (Şekil 1). Kars ili doğal ve beşeri özellikler bakımdan; batı ve güneydeki dağlık alanlar, İlin merkezi kısmındaki bulunan Yüksek plato sahası ve İlin güneyindeki Aras Vadisi olarak üç ayrı alana ayrılmaktadır.

İlin dağlık morfolojiye sahip alanlarını İli batıdan çevreleyen Allahuekber Dağları ve İli güneyden çevreleyen Aras Güneyi Dağları oluşturmaktadır. Ortalama irtifası 3000 metreyi aşan bu dağlık alanların çevrelerindeki plato düzlükleri ve vadi tabanlarıyla irtifa fark1 yer yer 1500- 2000 metreyi bulmakta olup eğim değerleri de oldukça fazladır (Demir, 2013). İlin diğer illerle sınır alanlarını oluşturan bu dağlık alanlarda irtifa ve karasallık etkisiyle İl genelinde etkili olan sert karasal iklim koşullarının en ağır türü yaşanmaktadır. İlin dağlık alanlarında yılın büyük kısmında donmuş durumdaki arazi kısa geçen yaz döneminde Alpin çayır bitkileri tarafından örtülmekte olup bu alanlar bu nedenle hayvancılık faaliyetlerini imkân sağlayabilen yayla alanı olarak kullanılmaktadır (Demir, 2016) (Şekil 1).

İlde plato morfolojisi gösteren ana alan, ortalama 2000 metre irtifaya sahip güneybatı kuzeydoğu doğrultusunda uzanan Kars Platosu üzerinde bulunmaktadır. Bu alanda platonun uzanış doğrultusunda Sarıkamış, Selim, Merkez, Digor, Susuz, Arpaçay, Akyaka İlçeleri yer almaktadır. İl arazilerinin \%66'sını oluşturan genel olarak akarsular tarafından derin şekilde parçalanmış yüksek irtifalı düzlüklerin hâkim olduğu klasik plato morfolojisi sunan bu arazisinin büyük kısmı pliyosen yaşlı bazaltik volkanik örtüyle, küçük bir kısmı ise neojen yaşlı göl çökelleri ve kuaterner yaşlı alüvyonlarla örtülüdür (MTA, 2008). Plato alanında mevcut morfolojik özelliklerin baskın etkisiyle oldukça soğuk ve uzun kış bir dönemi, serin ve nispeten yağışlı geçen kısa yaz dönemi yaşanmakta olup sert karasal iklim özellikleri hâkimdir (DMİGM, 2016). Kars Plato alanının büyük kısmını örten genç yaşlı bu volkanik arazilerde, Çernozyumlar gelişmiştir (Atalay, 2008). Plato alanında olumsuz klimatik koşullar nedeniyle klasik tarım faaliyetleri oldukça kısıtlanmış olup ürün verimi oldukça düşüktür. $\mathrm{Bu}$ nedenle beşeri ve ekonomik 
faaliyetler verimliliği düşük olsa da büyük oranda büyükbaş mera hayvancılığına dayanmaktadır (Demir, 2016).

İlde morfolojik bakımdan üçüncü bir grup arazi Kağızman ilçesi ve kırsal yerleşimleriyle Digor ve Sarıkamış ilçelerine ait bir kısım kırsal yerleşmenin yer aldığı batı doğu yönünde uzanan Aras Vadisi'nde bulunmaktadır. Aras Nehri tarafindan Kars volkanik platosunun derin şekilde yarılmasıyla oluşan İl arazilerinin \%16'sını oluşturan, ortalama 1251 metre taban irtifasına sahip olan bu vadide, vadi tabanıyla onu çevreleyen plato düzlükleri ve dağlar arasında irtifa fark1 1500-2000 metreyi bulurken vadi yamaçlarının eğim değerleri oldukça fazladır (MTA, 2008). İl geneline nispetle irtifası düşük olan bu alanda bu nedenle soğuk bir kış dönemi, sıcak ve nispeten kurak geçen yaz dönemine sahip sert karasal iklim özellikleri görülmektedir (Demir, 2018). Mevcut morfolojik ve klimatik nedenlere bağl1 olarak bu alanda tarım, hayvancılık ve diğer beşeri faaliyetler oldukça kısıtlanmıştır. Aras vadisinde eğiminin düşük olduğu belli yerlerde alüvyon örtüleri üzerinde düşük verimli meyvesebzecilik üretimi; miyosen yaşlı tuzlu, alkali çökeller üzerinde gelişmiş kahverengi bozkır toprak özelliği gösteren bu nedenle tarımın kısıtlandığı vadi yamaçlarında ise küçükbaş hayvancılık faaliyetleri yapılabilmektedir (Atalay, 2003).

\section{AMAÇ, VERİ VE YÖNTEM}

$\mathrm{Bu}$ araştırmada, CORINE sistemine göre Kars İlinde arazi örtüsü/arazi kullanımında periyodik olarak meydana gelen değişimlerin tespit edilmesi, bu değişimleri etkileyen doğal, beşeri çevre faktörleri ve arasındaki ilişkilerin belirlenmesi ve arazi kullanımının gelecekteki durumunun projeksiyone edilmesi amaçlanmıştır.

Araştırmada; Avrupa Çevre Ajansı CORINE (Coordination of Information on the Environment) tarafindan arazi örtüsü/arazi kullanımının tespiti amacıyla uydu görüntüleri üzerinden bilgisayar destekli görsel yorumlama metodu ile üretilmiş olan veri setleri temel malzemeyi oluşturmaktadır. Araştırmada CORINE arazi örtüsü/arazi kullanımı sistemindeki ilk örneklem yılını temsil eden 1990, ara örneklem 2000 yılı ve son örneklem yılını temsil eden 2018 yılına ait vektör verileri kullanılmıştır (COPERNICUS, CORINE 1990; 2018) (Tablo 1).

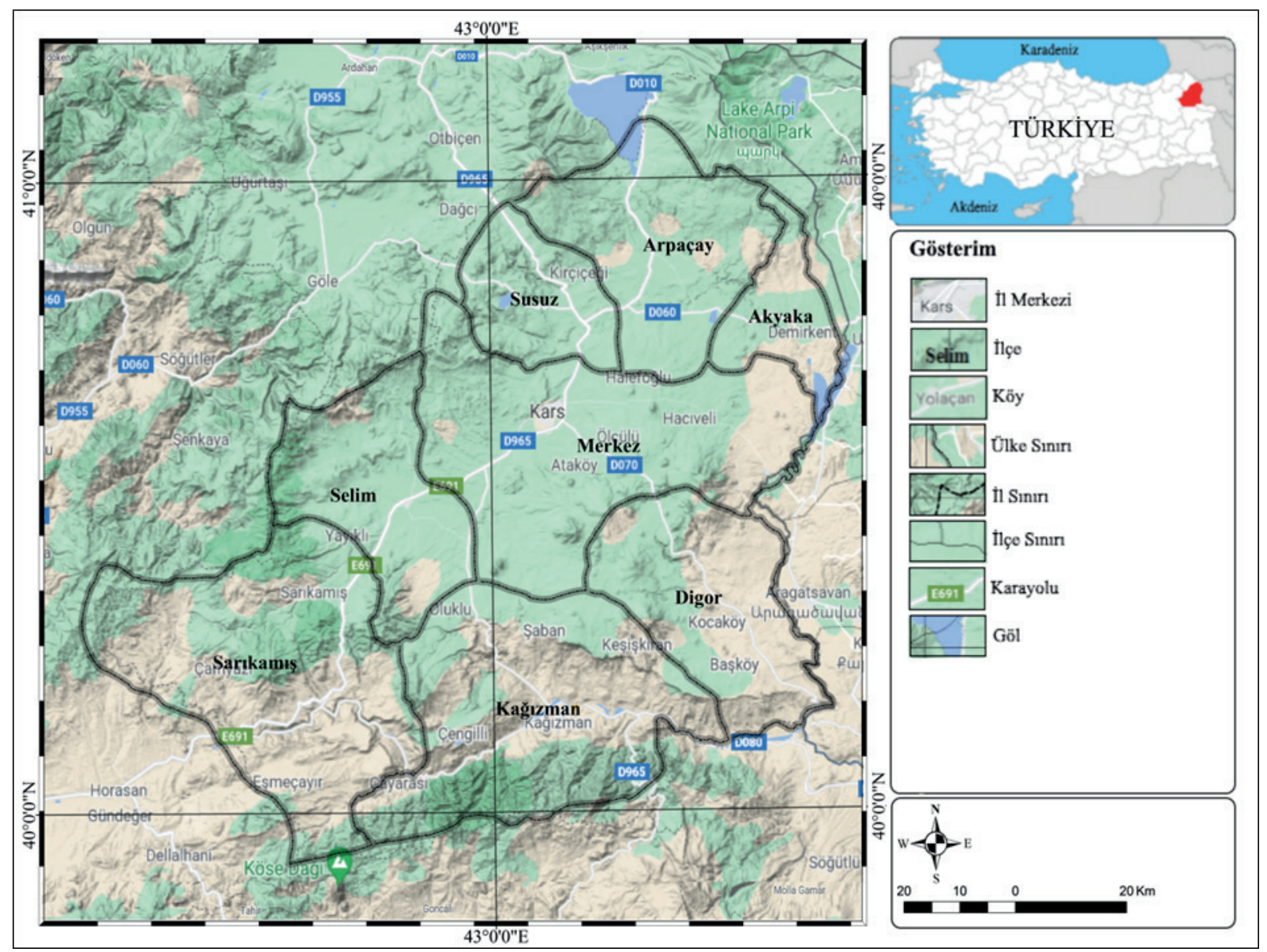

Şekil 1: Kars İlinin Lokasyonu (www.mapsgoogle.com. programı kullanılarak çizilmiştir).

Figure 1: Location of Kars Province. 
Tablo 1: CORINE Arazi Örtüsü/Arazi Kullanımı Veri Setleri Genel Öz Değerleri (1990, 2018).

Table 1: CORINE Land Cover / Land Use Data Sets General Core Values (1990, 2018).

\begin{tabular}{|c|c|c|c|}
\hline & CLC1990 & CLC2006 & CLC2018 \\
\hline Uydu verileri & Landsat-5 MSS / TM & SPOT-4/5IRS P6 LISS III & Sentinel-2 Landsat-8 \\
\hline Zaman tutarlılığı & 1986-1998 & $2006+/-1$ Yll & 2017-2018 \\
\hline Geometrik doğruluk, uydu verileri & $\leq 50 \mathrm{~m}$ & $\leq 25 \mathrm{~m}$ & $\leq 10 \mathrm{~m}$ (Sentinel-2) \\
\hline Minimum. Eşleşme birimi / genişlik & $25 \mathrm{ha} / 100 \mathrm{~m}$ & $25 \mathrm{ha} / 100 \mathrm{~m}$ & $25 \mathrm{ha} / 100 \mathrm{~m}$ \\
\hline Geometrik doğruluk, CLC & $100 \mathrm{~m}$ & 100 m'den daha iyi & 100 m'den daha iyi \\
\hline Tematik doğruluk, CLC & $\geq \% 85$ & $\geq \% 85$ & $\geq \% 85$ \\
\hline Tematik doğruluk, CHA & - & $\geq \% 85$ & $\geq \% 85$ \\
\hline
\end{tabular}

Kaynak: COPERNICUS, CORINE; 1990, 2000, 2018.

Araştırmanın başlangıç ve veri ön işleme aşamasında, temel malzemeyi oluşturan 1990, 2000 ve 2018 yıllarına ait CORINE vektör verilerinin hazır kabulü nedeniyle geometrik ve tematik öz değerler üzerinde herhangi bir düzeltme işlemi uygulanmamıştır. Buna rağmen Kars ili idari sınırlarına göre özelleştirilen 1990, 2006, 2018 yıllarına ait CORINE vektör verilerinin tematik doğruluğunun belirlenmesi amacıyla 1/25.000 ölçekli harita pafta indeksinde Kars iline ait mevcut 64 paftanın her biri için gelişigüzel olarak seçilen dört, toplamda 256 kontrol noktası belirlenmiştir. Bu kontrol noktalarındaki arazi örtüsü/ arazi kullanımı Google Engine ve HGM Küre uydu programları üzerindeki görüntülerle karşılaştırılarak kontrol edilmiştir. Bu noktalardan alınan kontrol değerlerinin ve CORİNE 2006 yılı verilerinin kullanımıyla yapılan doğruluk analizine göre Kars ilinin 2018 y1lı için CLC, $\geq \% 94$ Geometrik doğruluk ve $\geq \% 94$ Tematik doğruluk öz değerlerine sahip olduğu hesaplanmıştır (Şekil 2).

\subsection{Arazi Örtüsü/Arazi Kullanımı Değişimi Analizi}

Araştırmanım ikinci fazında araştırmanın temel malzemesini oluşturan 1990,2000 ve 2018 yıllarına ait CORINE vektör verilerinin her biri, araştırmanın amaç kısmında belirtilen arazi örtüsü/kullanımı ve değişiminin belirlenmesine yönelik olarak analiz edilmiştir. Değişim analizinde, iki farklı döneme ait arazi örtüsü/arazi kullanımı haritaları arasındaki değişim belirlenir. $\mathrm{Bu}$ haritalardaki değişiklikler, bir arazi örtüsü durumundan diğerine geçişlerdir. Araştırmalarda kullanılan arazi örtüsü/arazi kullanımı haritalarının ana ve alt sınıf sayısı fazlaysa arazi geçişlerin potansiyel kombinasyonunun karmaşık olması muhtemeldir (Dzieszko, 2014). Araştırmada değişism analizi amacıyla CORINE sisteminden elde edilen 1990, 2006 ve 2018 y1lına ait vektör verileri ARCGIS FOR DESKTOP ADVANCED 10.5 Programı kullanılarak raster verilerine dönüştürülmüştür. $\mathrm{Bu}$ dönüşüm işleminde her iki yıla ait raster veriler için hücresel boyut 30x30 m olarak ayarlanmış arazi kullanımındaki değişimin detaylı ve net şekilde belirlenmesi için düzey 3 sistematiği tercih edilmiştir. $\mathrm{Bu}$ işlem sonrasında elde edilen raster veri seti, Raster to ASCII işlem aracıyla İdrisi (RDC) programı formatına dönüştürülmek için hazır hale getirilmiştir. İlgili veriler İdrisi Terrset 18.31 programı GDAL Raster Conversion aracı kullanılarak programa intibak ettirilmiştir. Bu program üzerinde (land change) modülü kullanılarak arazi değişim matrisi oluşturulmuştur. Bu analizler sonucunda Kars ilinin 1990, 2000 ve 2018 yıllarına ait CORINE arazi örtüsü/arazi kullanımı veri setlerinin her biri için 5 ana arazi kullanımı sınıfına dağılım gösteren 23 alt arazi kullanım sınıfı tespit edilmiştir. Analizlerde Kars ilinin 1990 ve 2018 yıllarına ait CORINE “düzey 3" Arazi alt sinıfları arasında minimum 0,001 $\mathrm{km}^{2}$ ile maksimum $315 \mathrm{~km}^{2}$ arasında alana sahip 255 adet arazi geçişimi belirlenmiştir (Şekil 7).

\subsection{Arazi Örtüsü/Arazi Değişimi Potansiyeli}

Araştırma amaçlarından birini geçmişteki veya mevcut arazi örtüsü/arazi kullanımına dayalı olarak gelecekteki arazi örtüsü/ arazi kullanımın belirlenmesi oluşturmaktadır. Araştırmada bu amaçla Multi Layer Perceptron (MLP) neural networks tekniği kullanılmıştır. MLP en yaygın kullanılan Yapay Sinir Ağlarından (YSA) biri olup Rumelhart tarafindan tanımlanmıştır (Rumelhart, vd 1986). MLP tekniği gelecekteki senaryoları projelendirmek için önceki zamandan sonraki zamana kadar olan tarihsel değişime dayanmaktadır (Eastman 2012). MLP; girdi, gizli ve çıktı olmak üzere üç katmandan oluşur. MLP böylece doğrusal olmayan ilişkileri tanımlayabilir. YSA algoritmaları, girdiyi gizli katman ve çıktı katmanı boyunca 3.yayılan ileri beslemeli bir şekilde sunarak girdi değerleri, girdi katmanı düğümleri, gizli katman 3.4 düğümleri ve çıkış katmanı düğümleri için ağırlıkları hesaplar (Eastman 2012; Dzieszko 2014). MLP, modellenmekte olan geçişi yaşamış ve yaşamamış gridlerin sağladığı örnekler üzerinde çalışmaya başlar. Bu yöntem sinir ağlarına dayandığından, öncelikle MLP otomatik modda çalışır ve bu sayede hangi parametrelerin kullanılacağına ve verilerin daha iyi bir şekilde modellenmesi için nasıl değiştirilmesi gerektiğine kendi kararlarını verir. Modül, maksimum yineleme sayısı veya maksimum doğruluk oranına kadar yinelenir (Eastman 2012). 
Araştırmada değişim sürecindeki arazi sınıfları arasındaki geçiş potansiyeli belirlenmiş ve modellenmiştir. Araştırmada Kars ilinin 1990, 2000 ve 2018 yıllarına ait CORINE arazi örtüsü/arazi kullanımının verileri baz alınarak arazi geçişim potansiyeli matrisleri hazırlanmıştır. Bu işlem aşamasında İdrisi Terrset 18.31 programı, land change modelleri altındaki Transition Potentials modülünde çalışan MLP analizi için 5 ana arazi sınıfındaki 23 alt sınıfını için örnek talep edilmiştir. Örneklemin \%50'si eğitim, \%50'si test olarak kabul edilip, iteration 10000 olarak atanmıştır. Örneklem doğrulama oranı \%93,83 olmuştur. Bu yöntemde CORINE 1990 yılı önceki verileri, CORINE 2000 y1lı verileri ise son y1l verileri olarak kullanılarak 2018 yılı arazi kullanımı projeksiyone edilerek geçişim potansiyeli haritaları ve matrisleri oluşturulmuştur. Elde edilen sonuçlar kontrol modeli olarak kullanılan araştırma alanının 2018 yılına ait CORINE verisiyle karşılaştırılmıştır. MLP analizlerinde sadece Kars ilinin 1990, 2000 ve 2018 yıllarına ait CORINE arazi örtüsü/arazi kullanımının verilerinin incelenmesi amaçlandığ dikkate alınmamıştır (Tablo 2).

\subsection{Arazi Örtüsü/Arazi Değişim Potansiyeli Doğruluk Analizi}

Doğruluk Analizi, iki kategorik görüntü arasındaki uyum hakkında bilgi veren bir yöntemdir. Doğrulama, projeksiyone modelleme için karşılaştırması yapılan iki veya daha fazla veri ve haritanın uyuşma oranını gösterir (Pontius, 2000), Araştırmanın son fazında daha önce kontrol modeli olarak kullanılan Kars ilinin 2018 y1lına ait CORINE düzey 3 arazi örtüsü/arazi kullanım verileri yardımıyla 2018 yılı için oluşturulan projeksiyon modelinin doğruluk analizleri yapılmıştır. Bu amaçla, İdrisi Terrset 18.31 programındaki Land Change modülü altındaki, validation işlem bölmesi kullanılmıştır. Analizlerde 2018 yılı projeksiyone modelinin KAPPA değeri 0,94 , olarak tespit edilmiş olup i doğrulama değeri de bu tip araştırmalar için kabul edilen ortalamalara nispetle oldukça yüksektir (Pontius, 2000).

İle ait CORINE düzey "3" alt sınıfları içinde 15 âdeti \%90 üzerinde, sekiz âdeti ise \%48 ile \%90 arasında doğruluk oranı göstermiştir. Arazi alt sınıfları içinde en düşük doğruluk oranını \%48,8 ile "411" alt kodlu İç Bataklıklar ve \%68 ile "121" alt kodlu Devamlı Olmayan Şehir Yapısı arazileri göstermiştir. Genel olarak düzey "3" alt arazileri içinde benzer özellik gösteren ve bu nedenle aynı renkte algılanan arazi sınıflarının doğruluk oranı nispeten düşük çıkmıştır (Tablo 3).

\subsection{Arazi Örtüsü/Arazi Kullanımı Projeksiyonu}

Araştırmanın üçüncü fazında önceki analizlerden elde edilen Kars ili idari alanına ait CORINE verileri kullanılarak gelecekteki arazi örtüsü/arazi kullanımının projeksiyone edilmesi amacıyla İdrisi Terrset 1.12 programı kullanılarak analizler yapılmıştır. Bu amaçla; geçmiş dönemlerdeki ve mevcut arazi kullanımı verilerine bağlı olarak hem mekânsal hem zamansal değişiklikleri hem de arazi grupları arasındaki geçişimi modelleyip projeksiyone edebilme kabiliyetleri nedeniyle Markov zinciri

Tablo 2: CORINE "düzey 3" Kars Illinde Arazi Örtüsü/Arazi Kullanımı Geçiş Olasılıkları Matrisi (1990-218).

Table 2: Land Cover/Land Use transition probabilities matrix in Kars Province CORINE "level 3" classification.

\begin{tabular}{|c|c|c|c|c|c|c|c|c|c|c|c|c|c|c|c|c|c|c|c|c|c|c|c|}
\hline Simif Kodu & 111 & 112 & 121 & 124 & 131 & 133 & 142 & 211 & 212 & 231 & 242 & 243 & 311 & 312 & 313 & 321 & 324 & 331 & 332 & 333 & 411 & 511 & 512 \\
\hline 111 & 0.9887 & 0.0000 & 0.0000 & 0.0000 & 0.0000 & 0.0000 & 0.0000 & 0.0000 & .0000 & 0.0000 & .0000 & 0.0000 & .0000 & 0.0000 & .0000 & 0.0000 & .0000 & 0.0000 & .0000 & 0.0000 & & .0000 & .0000 \\
\hline 112 & & & & & & & & & & & & & & & & & & & & & & & \\
\hline 121 & 0000 & 0000 & 0.9983 & 0.0000 & 0000 & 0.0000 & .0000 & 0.0007 & 0000 & 0.0010 & 0000 & 0.0000 & 0.0000 & 0.0000 & 0.0000 & 0.0000 & 0.0000 & 0.0000 & 0.0000 & 0.0000 & 0.0000 & 0.0000 & 0.0000 \\
\hline 124 & & 0000 & 0000 & & & 0.0000 & & & & & & & & & & & & & & & & 000 & \\
\hline 31 & & 0000 & & 0 & & 0000 & & & & & & & & & & & & & & & & & 000 \\
\hline 133 & .0000 & 0004 & 9239 & 0.0000 & 0.0000 & 0.9438 & .0000 & .0000 & 0221 & 0.05 & 00 & 0.0000 & 0.00 & 0.0000 & 0.0000 & 0.0000 & 0.0000 & 0.0000 & 0.0000 & 0.0000 & 0.0000 & 0.0000 & 0.0000 \\
\hline 142 & 0000 & 0040 & .0000 & .0000 & .0000 & 0.07 & 0.5612 & & & & & & & 02 & 0000 & 000 & 1591 & 000 & 000 & 0.2018 & 0.0000 & 0.0000 & 0.0000 \\
\hline & & 0 & & & & & & & & & & & & & & & & & & & & & \\
\hline 212 & 0.0000 & 0043 & 0.0004 & 0.0000 & .0018 & 0.0000 & 0.0000 & 0.0443 & 8784 & 0.01 & .0267 & 0.0166 & 0.0000 & 0.0000 & 0.0000 & 0.0072 & 0.0000 & 0.0008 & 0.0002 & 0.0036 & 0.0001 & 0.0000 & 0.0004 \\
\hline 231 & 000 & 0023 & 0042 & 0 & 027 & 17 & 0000 & & 041 & & & & & & & & 0001 & 001 & 0.0000 & & 0.0030 & 0.0002 & 0.0004 \\
\hline & & & & 0 & & & & & & & & & & & & & & & & & & & \\
\hline 243 & 0000 & 0007 & .0000 & 0.0000 & 0.0009 & 0.0012 & 0.0000 & 0.1126 & 0144 & 0.05 & 0918 & 0.5931 & 0.0000 & 0.0004 & 0.0003 & 0.0 & 0.0038 & 003 & 0.0068 & 329 & 0.0011 & 0.0000 & 0.0005 \\
\hline 31 & .0000 & .0000 & .0000 & 0.0000 & 0.0000 & 0.0000 & 0.0000 & & 000 & & & & & 00 & & & 1800 & 000 & 0.0100 & 066 & 0.0000 & 0.0000 & 0.0000 \\
\hline & & 0 & 0000 & 0 & 0000 & 0.00 & & & & & & & & & & & 302 & & & & 0.0000 & 000 & \\
\hline 3. & 0.0000 & 0.0000 & .0000 & 0.0000 & .0000 & 0.0000 & 0.0000 & 0.0033 & 0.0000 & 0.00 & 0.0000 & 10 & 0.00 & 0.0 & 0.7 & 0.0 & 0.2 & 00 & 0.0 & 43 & 0.0000 & 000 & 0.0000 \\
\hline 321 & 0.0000 & 0.0004 & 0.0001 & 0.0000 & 0.0000 & 0.0000 & 0.0003 & 0.0253 & 0.0002 & 0.1198 & 0.0114 & 0.0378 & 0.0000 & 0.0009 & 0.0001 & 0.7401 & 0.0078 & 0.0000 & 0.0077 & 0.0480 & 0.0001 & 0.0000 & 0.0000 \\
\hline 324 & 0.0000 & .0000 & 0.0000 & 0.0000 & 0.0000 & 0.0000 & 0.0000 & 0.0000 & 0.0000 & 0.0000 & .0027 & 0.0044 & 0.0014 & 0.0172 & 0.0021 & 0.2046 & 0.7528 & 0.0000 & 0.0044 & 0.0104 & 0.0000 & 0.0000 & 0.0000 \\
\hline 331 & 0.0000 & 0.0000 & 0.0000 & 0.0000 & 0.0000 & 0.0000 & 0.0000 & 0.0000 & 0000 & 0.0000 & .0538 & 0.0630 & 0.0000 & 0.0000 & 0.0000 & 0.0000 & 0.0000 & 0.7546 & 0.0000 & 0.0102 & 0.0000 & 0.1182 & 0.0000 \\
\hline & 0.0000 & .0005 & 0.0000 & 0.0000 & 0.0000 & 0.0007 & 0.0001 & 0.0002 & 0.0001 & 0.0070 & 0.0030 & 0.0047 & 0.0000 & 0.0000 & 0.0000 & 0.0509 & 0.0028 & 0.0000 & 0.8853 & 0.0442 & 0.0000 & 0.0002 & 0.0001 \\
\hline 333 & 0.0000 & 0.0004 & 0.0000 & 0.0000 & 0.0005 & 0.0006 & 0.0000 & 0.0051 & 0.0005 & 0.0478 & 0028 & 0.0277 & 0.0000 & 0.0002 & 0.0001 & 0.1049 & 0.0019 & 0.0002 & 0.1020 & 0.7052 & 0.0000 & 0.0001 & 0.0001 \\
\hline 411 & 0.0000 & 0026 & 0.0012 & 0.0000 & 0.0000 & 0.0000 & 0.0000 & 0.0498 & 0.0094 & 0.0330 & 0.0000 & 0.0005 & 0.0000 & 0.0000 & 0.0000 & 0.0000 & 0.0000 & 0.0000 & 0.0000 & 0.0000 & 0.5612 & 0.0104 & 0.3318 \\
\hline & 0.0000 & 0000 & 0.0000 & 0.0000 & 0.0000 & 0.0000 & 0.0000 & 0.0175 & 0.0000 & 0.0000 & 0.0608 & 0.0000 & 0.0000 & 0.0000 & 0.0000 & 0.0140 & 0.0026 & 0.0535 & 0.0042 & 0.0033 & 0.0000 & 0.7684 & 0.0758 \\
\hline 512 & 0.0000 & 0.0000 & 0.0000 & 0.0000 & 0.0000 & 0.0000 & 0.0000 & 0.0015 & 0.0026 & 0.0005 & 0.0006 & 0.0004 & 0.0000 & 0.0000 & 0.0000 & 0.0003 & 0.0000 & 0.0000 & 0.0000 & 0.0002 & 0.0215 & 0.0000 & 0.9725 \\
\hline
\end{tabular}


Tablo 3: CORINE "düzey 3" Kars Illinde Arazi Örtüsü/Arazi Kullanımı Doğruluk Analizi (2018).

Table 3: CORINE "level 3" Land Cover/Land Use Accuracy Analysis in Kars Province (2018).

\begin{tabular}{lll}
\hline Sınıf Kodu & & Kappa 2018 P \\
\hline 111 & Devamlı şehir yapısı & 0,9256 \\
112 & Devamlı olmayan şehir yapısı & 0,6839 \\
121 & Endüstriyel veya ticari birimler & 0,9141 \\
124 & Hava alanları & 0,9990 \\
131 & Maden çıkarım alanları & 0,9449 \\
133 & Inşaat sahaları & 0,8218 \\
142 & Spor ve Dinlenme Alanları & 0,9504 \\
211 & Sulanmayan tarımsal araziler & 0,9833 \\
212 & Sürekli sulanan araziler & 0,9936 \\
231 & Meralar & 0,9601 \\
242 & Karışık tarım alanları & 0,9821 \\
243 & Doğal bitki örtüsü ile birlikte tarım alanları & 0,9999 \\
311 & Geniş yapraklı ormanlar & 0,9436 \\
312 & Kozalaklı ağaç ormanlar & 0,9915 \\
313 & Karışık ormanlar & 0,9228 \\
321 & Doğal çayırlıklar & 0,8305 \\
324 & Geçici orman- çalılık & 0,8911 \\
331 & Sahiller, kumsallar ve kum düzlükleri & 0,8972 \\
332 & Çıplak kayalık & 0,8407 \\
333 & Seyrek bitkili alanlar & 0,9120 \\
411 & Iç bataklıklar & 0,4888 \\
511 & Suyolları & 0,8398 \\
512 & Su kütleleri & 0,9891 \\
Kappa 2018 P & 0,9383 \\
\hline
\end{tabular}

modeli (Eastman, 2009) kullanılmıştır. Markov zinciri modeli, karmaşı sistemlerde geometrik varyasyonu analiz yeteneğine sahip olan Hücresel Otomat Analizi (Cellular Automata Analysis) ile iki farklı görüntünün çapraz tablolamasıyla oluşturulan geçiş olasılığı matrisinin (Transition Probability Matrix) birleşimidir (Clark Lab, 2018). Markov zinciri modelinin, mevcut arazi kullanım türleri arasında iki yönlü geçişimleri tahmin etme avantajı ve arazi kullanımını uzun süreli projeksiyone etmede regresyon tabanlı modellerden daha iyi performans gösterdiği kanıtlanmıştır (Pontius, \& Malanson, 2005, s, 244).

Araştırmada İlin gelecekteki arazi kullanımının projeksiyone edilmesi amaciyla, daha önceki fazda üretilen CORINE arazi örtüsü/arazi kullanımı değişim potansiyeli verileri temele alınmıştır. Bu veriler İdrisi Terrset 1.12 programının Change Prediction modülündeki Markov zinciri yöntemiyle analiz edilmiştir. $\mathrm{Bu}$ yöntem, daha önce hesaplanan geçiş potansiyellerine göre belirli bir tarihte oluşacak değişim miktarını belirler. Prosedür, geçiş potansiyellerinin geleceğe yönelik bir projeksiyonuna dayanarak, daha sonraki bir tarihten tahmin tarihine tam olarak ne kadar arazi geçişinin bekleneceğini belirler ve prosedür bir geçiş olasılıkları matrisi oluşturur (Eastman, 2012; Dzieszko, 2014 Araştırmada kullanılan model İdrisi Terrset 1.12 programının Change Prediction modülü altında çalıştırılmıştır. Araştırmada yapılacak olan arazi değişim projeksiyonun daha isabetli sonuç vermesi amaciyla projeksiyon hedef y1lı kısa süreli tutularak 2040 olarak belirlenmiştir. Bu kapsamda yapılan Markov Analizlerinde; 2018 yılı projeksiyon kontrol verileri kullanılarak 2040 yılı için Geçiş Olasılık Matrisi ve Geçiş Alanları Matrisleri oluşturulmuştur. Arazi Projeksiyon işlemlerinde $0,01 \mathrm{Km}^{2}$ 'den düşük alana sahip değişimler ihmal edilerek dikkate alınmamıştır. Analizlerden elde edilen sonuçlar çıktı haritası ve değişim matrisi, kontrol modeli olarak kabul edilen 2018 yılı verileriyle çapraz olarak karşılaştırılmıştır. Bu analizlerde daha önce yapılan arazi değişim analizlerine paralel olarak 5 ana arazi örtüsü/arazi kullanımı sınıfına dağılım gösteren 23 alt arazi kullanım sınıfının bulunabileceği projeksiyone edilmiştir.

\section{ANALIZZ VE BULGULAR}

\subsection{Arazi Örtüsü/Arazi Kullanımı Gruplarının İldeki Dağılımı, Durumu ve Değişimi}

CORINE 1990 ve 2018 y1lı veri setleri kullanılarak yapılan analizlere göre 10196 km² yüz ölçümüne sahip Kars ilinde, 5 ana arazi örtüsü/arazi kullanım sınıfındaki 23 arazi alt sınıfına ait arazi bulunmaktadır (Şekil 2, Şekil 3). İldeki arazi örtüsünün \%2'sini oluşturan $160 \mathrm{~km}^{2}$ 'si "1"ana kodlu Yapay Yüzeyler genel sinıfinda, \%59'unu oluşturan 3984 km²'si “2”ana kodlu Tarım Alanları genel sınıfında, \%39'unu oluşturan 3946 km²'si “3”ana kodlu Orman ve Yarı Doğal Alanlar genel sinıfinda, \%0,2'sini oluşturan 17 km²'si “4”ana kodlu Islak Alanlar genel sınıfında, \%1'ini oluşturan $89 \mathrm{~km}^{2}$ 'si "5" ana kodlu Su Toplulukları genel sınıfinda bulunmaktadır. Kars iline ait 1990 ve 2018 yılı CORINE verileri kullanılarak yapılan karşılaştırma ve oluşturulan değişim matrisine göre, İl yüzölçümünün $\% 12,84$ 'üne denk gelen toplam $1310 \mathrm{~km}^{2}$ alanda arazi örtüsü/ arazi kullanımı değişim meydana gelmiştir (Şekil 5).

\subsection{1. "1" Yapay Yüzeyler}

CORINE arazi örtüsü/arazi kullanım sınıflaması verilerine göre toplam 10196 km² yüz ölçümüne sahip olan Kars ili arazisinin \%2'sini oluşturan $160 \mathrm{~km}^{2}$ 'si beşeri ve ekonomik faaliyetlerin tamamına yakınının icra edildiği "1"ana kodlu Yapay Yüzeyler genel sınıfinda bulunmaktadır. Kars ilinde "1" genel kodlu Yapay Yüzeyler genel sınıfındaki arazilerin önemli bölümü İlin idari ve ticari merkezi durumundaki Merkez İlçesi ve çevresinde, geriye kalan kısmı ise kentsel karakteristik gösteren Sarıkamış ve Kağızman ilçe merkezleri ve çevresinde yoğunlaşmıştır (Demir, 2013) (Şekil 5). 
Kars ilinin 1990-2018 yılları CORINE arazi örtüsü/arazi kullanım mukayesesine göre " 1 " ana sınıfında en önemli oransal değişiklik "1" sınıf kodlu Yapay Yüzeyler genel sınıfında meydana gelmiştir. Yerleşim alanları ve çevrelerindeki yapılar ve altyap1 unsurlarını kapsayan bu ana sınıfa dâhil arazilerin 1990 yılında toplam alanı $96,5 \mathrm{~km}^{2}$ ile İl genel alanının \%0,98'ini oluştururken, 2018 yılı itibariyle bu arazi grubunun genel alanı \%65,8 artarak İl genel alanının \%1,6'sına denk gelen $160 \mathrm{~km}^{2}$ ye ulaşmıştır. CORINE verilerine göre 1990 yılından 2018 yılına kadar geçen süreçte "1" ana kodlu Yapay Yüzeyler genel gurubunda "111" kodlu Devamlı Şehir Yapısı arazileri dışındaki tüm arazi alt sınıflarına ait arazi varlıklarında pozitif yönlü artış meydana gelmiştir (Şekil 4, Şekil 5). İlde beşeri faaliyetlerin yürütüldüğ̈̈ bu grup arazilerinin pozitif yönlü genel değişim oranının oldukça yüksek olması, İl dışına giden nüfus göçlerinin olumsuz etkilerine rağmen çoğunlukla kamu yatırımlarına dayalı olarak meydana gelen ekonomik gelişime dayanmaktadır (Demir, 2015).
CORINE arazi örtüsü/arazi kullanımı verileri değişim matrisi verilerine göre Kars ilinde "1" ana kodlu Yapay Yüzeyler genel sınıf içinde toplam $27,9 \mathrm{~km}^{2}$ arazi bu ana sınıfın kendi içindeki alt arazi sınıflarına dönüşmüştür. Geriye kalan arazilerin \%86,6'sını oluşturan 24,1 km²'si "2" ana kodlu Tarım Alanları ana sınıfina, \%11,8'ini oluşturan 3,29 km'si "3" ana kodlu Orman ve Yarı Doğal Alanlar ana sınıfına, \%0,2'sini oluşturan $0,051 \mathrm{~km}^{2}$ 'si "4" ana kodlu Islak Alanlar ana sinıfina, \%1,5'ini oluşturan 0,41 km²'si "5" ana kodlu Su Toplulukları ana sınıfi arazilerine dönüşmüştür (Şekil 7).

İlde "1" ana sınıf kodlu Yapay Yüzeyler arazilerine dönüşen diğer ana arazi sınıflarına ait toplam $90,9 \mathrm{~km}^{2}$ arazinin \%93'ünü oluşturan 84,6 km²'si "2" ana kodlu Tarım Alanları ana sınıfından, $\% 7,4$ 'ünü oluşturan 6,26 km²'si "3" ana kodlu Orman ve Yarı Doğal Alanlar ana sınıfından, \%0,086'sını oluşturan 0,07 km²'si "4" ana kodlu Islak Alanlar ana sınıfından dönüşmüştür. Arazi değişim matrisi 1990 ve 2018 yılları mukayesesine göre İlde " 1 " ana sınıf kodlu Yapay Yüzeyler arazileri lehine $63 \mathrm{~km}^{2}$ kazanç meydana gelmiştir (Şekil 7).

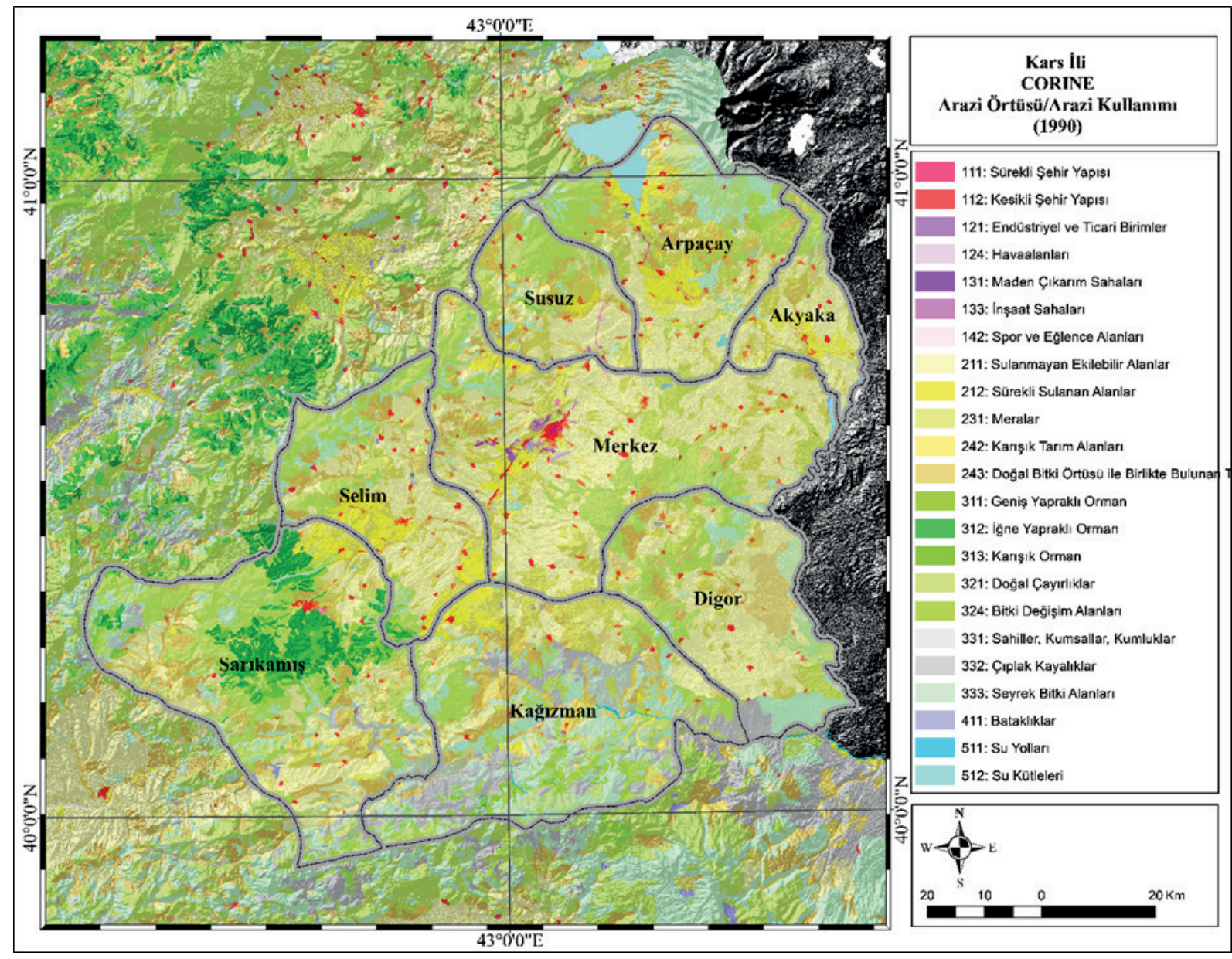

Şekil 2: CORINE "düzey 3" sınıflandırmasına göre Kars İlinde Arazi Örtüsü/Arazi Kullanımı Dağılımı (1990). Figure 2: Distribution of Land Cover in Kars Province According to CORINE "level 3" Classification (1990). 


\begin{tabular}{|c|c|c|c|c|c|c|c|}
\hline \multirow{2}{*}{$\begin{array}{c}\text { Dūzey "1" } \\
\text { Kodu }\end{array}$} & \multirow{2}{*}{$\begin{array}{c}\text { CORinE Düzey "1" } \\
\text { Arazi Örtüsü/Arazi Kullanımı SInntit }\end{array}$} & \multirow{2}{*}{$\begin{array}{l}\text { CORiNE Düzey "3" } \\
\text { Arazi Sinntí Kodu }\end{array}$} & \multirow{2}{*}{ CORiNE Dūzey "3" Arazi Örtūsü/Arazi Kullanımı Sınıfı } & \multicolumn{2}{|c|}{ CORinE Dūzey "3" Arazi Örtüsü/Arazi Kullanımı } & \multicolumn{2}{|c|}{ CORiNE Dūzey "1" Arazi Örtüsū/Arazi Kullanım } \\
\hline & & & & Alanı (km2) & Oran (96) & Alanı (km2) & $\operatorname{Oran}(\%)$ \\
\hline \multirow{7}{*}{1} & \multirow{7}{*}{ Yapay Yüzeyler } & 111 & Devamlı Şehir Yapısı & 2,87 & $0,03 \%$ & \multirow{7}{*}{96,5} & \multirow{7}{*}{$0,9 \%$} \\
\hline & & 112 & Devamlı Olmayan Şehir Yapısı & 84,55 & $0,82 \%$ & & \\
\hline & & 121 & Endüstriyel veya Ticari Birimler & 2,10 & $0,02 \%$ & & \\
\hline & & 124 & Hava Alanları & 2,12 & $0,02 \%$ & & \\
\hline & & 131 & Maden Çıkarım Alanları & 2,29 & $0,02 \%$ & & \\
\hline & & 133 & Inşaat Sahaları & 1,10 & $0,02 \%$ & & \\
\hline & & 142 & Spor Ve Dinlenme Alanları & 1,50 & $0,01 \%$ & & \\
\hline \multirow{5}{*}{2} & \multirow{5}{*}{ Tarım Alanları } & 211 & Sulanmayan Tarımsal Araziler & 2983,4 & $29,28 \%$ & \multirow{5}{*}{5692,9} & \multirow{5}{*}{$55,8 \%$} \\
\hline & & 212 & Sürekli Sulanan Araziler & 383,8 & $3,77 \%$ & & \\
\hline & & 231 & Meralar & 1164,0 & $11,40 \%$ & & \\
\hline & & 242 & Karışık Tarım Alanları & 260,4 & $2,54 \%$ & & \\
\hline & & 243 & Doğal Bitki Örtüsü ile Birlikte Bulunan Tarım Alanla & 901,3 & $8,83 \%$ & & \\
\hline \multirow{8}{*}{3} & \multirow{8}{*}{ Orman ve Yarı Doğal Alanlar } & 311 & Geniş Yapraklı Ormanlar & 4,6 & $0,05 \%$ & \multirow{8}{*}{4309,6} & \multirow{8}{*}{$42,3 \%$} \\
\hline & & 312 & Kozalaklı Ağaç Ormanlar & 268,2 & $2,63 \%$ & & \\
\hline & & 313 & Karışık Ormanlar & 60,9 & $0,59 \%$ & & \\
\hline & & 321 & Doğal Çayırlıklar & 2208,7 & $21,67 \%$ & & \\
\hline & & 324 & Geçici Orman- Çalılık & 160,7 & $1,57 \%$ & & \\
\hline & & 331 & Sahiller, Kumsallar ve Kum Düzlükleri & 6,8 & $0,07 \%$ & & \\
\hline & & 332 & Çıplak Kayalık & 361,1 & $3,54 \%$ & & \\
\hline & & 333 & Seyrek Bitkili Alanlar & 1238,6 & $12,15 \%$ & & \\
\hline 4 & Islak Alanlar & 411 & İç Bataklıklar & 17,83 & $0,17 \%$ & 17,8 & $0,2 \%$ \\
\hline \multirow{2}{*}{5} & \multirow{2}{*}{ Su Toplulukları } & 511 & Suyolları & 8,08 & $0,08 \%$ & \multirow{2}{*}{78,8} & \multirow{2}{*}{$0,8 \%$} \\
\hline & & 512 & Su Kütleleri & 70,83 & $0,69 \%$ & & \\
\hline & & & Toplam & 10196 & $100 \%$ & 10196 & $100 \%$ \\
\hline
\end{tabular}

Şekil 3: CORINE "düzey 3" Sınıflandırmasına Göre Kars İlinde Arazi Örtüsü/Arazi Kullanımı (1990).

Figure 3: Land Cover / Land Use in Kars Province According to CORINE "level 3" Classification (1990).

CORINE verilerine göre Kars ilinde 1990 yılından 2018 y1lına kadar geçen süreçte "1" ana kodlu Yapay Yüzeyler genel sınıfında pozitif yönlü en önemli oranda değişim “112" alt kodlu Devamlı Olmayan Şehir Yapılarına ait alanlarda meydana gelmiştir. Bu alt grupta yer alan araziler 1990 yılında 84,55 $\mathrm{km}^{2}$ yüzölçümle İldeki tüm arazilerin $\% 0,82$ 'sini oluştururken 2018 yılına kadar geçen süreçte $\% 42$ artışla il arazilerinin \%1,18'ini oluşturan 120,9 km²'ye ulaşmıştır (Şekil 4, Şekil 5). İlde 1990 yılından 2018 yılına kadar geçen 30 yıllık süreçte 8 ilçe merkezi, 383 köyden oluşan idari birim sayısında herhangi bir değişim meydana gelmemesine rağmen bu arazi alt sınıfındaki değişimin büyük oranda ildeki yerleşim merkezleri çevresinde tarım ve hayvancılık faaliyetlerini destekleyen yapıların inşasından kaynaklandığı anlaşılmaktadır. $\mathrm{Bu}$ alt sınıftaki arazi türleri arası geçişimi gösteren değişim matrisi bu sınıf arazilerine dönüşen toplam $62,5 \mathrm{~km}^{2}$ diğer alt sinıf arazisinin \%65,3'ünü oluşturan 40,84 km²'sinin "231" Kodlu Karışık Tarım Alanlarından dönüştüğünü göstererek bu durumu teyit etmektedir (Şekil 8). İlde "112" alt kodlu Devamlı Olmayan Şehir Yapılarından diğer arazi alt sınıflarına dönüşen 26,95 km² arazinin \%27'sini oluşturan 7,38 km²'si Karışı Tarım Alanları alt sınıfına geçmiştir. İlde arazi geçişiminim ele alındığ1 1990 ve 2018 yıllarında “112” alt kodlu Devamlı Olmayan Şehir Yapılarına ait araziler lehine $35,54 \mathrm{~km}^{2}$ kazanç meydana gelmiştir (Şekil 7).

\subsection{2. "2" Tarım Alanları}

Kars İlinin büyük kısmının ortalama 1971 metre irtifaya sahip fazla eğimli olmayan Kars Platosu üzerinde yer alması nedeniyle tarım arazilerinin oranı oldukça fazladır. Buna rağmen ilde sert karasal İklim koşullarının hâkim olması nedeniyle tarımsal faaliyetler büyük oranda kısıtlanmış olup bu koşullara uygun olarak tarım arazilerinin tamamına yakınında hayvancılık ihtiyaçlarının karşılanmasına yönelik olarak tahıl ve yem bitkileri tarımı yapılmaktadır (Demir, 2016). İlde bu özellikteki tarım arazilerinin büyük kısmı Kars Platosu üzerindeki Merkez İlçe ve çevresinde toplanmış olup bu özellikteki araziler İl genel alanının \%58,7'sine denk gelen $5984 \mathrm{~km}^{2}$ alana yayılmaktadır (Şekil 4, Şekil 5).

Kars iline ait CORINE 1990 ve 2018 yılları verileri karşılaştırmasına göre arazi örtüsü/arazi kullanımında oransal olarak en önemli ikinci değişiklik " 2 " ana kodlu Tarım Arazileri genel sınıfinda meydana gelmiştir. Bu gruba dâhil araziler 1990 y1lında toplam $5693 \mathrm{~km}^{2}$ ile İl genel alanının \%55,8'ini oluştururken, 2018 yılı itibariyle bu arazi gurubunun genel alanı $\% 5,1$ artarak İl genel alanının \%58,7'sine denk gelen $5984 \mathrm{~km}^{2}$ alana ulaşmıştır (Şekil 4, Şekil 5). Bu arazi gurubunda meydana gelen artışın kaynağının belirlenmesi amacıyla hazırlanan değişim matrisi ve uydu görüntüleri üzerinden yapılan arazi analizleri bu ana sınıfta daha çok tarımsal amaçlara yönelik 
olarak "3" ana kodlu Orman ve Yarı Doğal arazilerin dönüştürüldüğünü göstermektedir.

Kars ilinin 1990 ve 2018 yılları CORINE veri setleri kullanılarak oluşturulan arazi değişim matrisi "2" ana sınıf kodlu Tarım Alanları arazilerine dönüşen toplam $685 \mathrm{~km}^{2}$ arazinin \%3,5'ini oluşturan 24,1 km²'sinin "1" ana kodlu Yapay Yüzeyler ana sınıfından, \%96'sını oluşturan $657 \mathrm{~km}^{2}$ 'sinin "3" ana kodlu Orman ve Yarı Doğal Alanlar ana sınıfindan, \%0,03'ünü oluşturan 1,91 km²'sinin "4" ana kodlu Islak Alanlar ana sinıfından, 0,02'sini oluşturan 1,28 km²'sinin "5" ana kodlu Su Toplukları Alanları ana sınıfından dönüştüğünü göstermektedir.

Arazi değişim matrisi "2" ana kodlu Tarım Alanları genel sınıfından içinde toplam $811 \mathrm{~km}^{2}$ arazinin bu ana sınıfın kendi içindeki alt arazi sınıflara dönüştüğünü göstermektedir. İlde "2" ana sınıf kodlu Tarım Alanları genel sınıfindan diğer ana arazi sinıflarına dönüşen toplam $393 \mathrm{~km}^{2}$ arazinin \%21,5'ini oluşturan $84,6 \mathrm{~km}^{2}$ 'si "1" ana kodlu Yapay Yüzeyler ana sinıfina, \%75,8'sini oluşturan 298 km²'si "3" ana kodlu Orman ve Yarı Doğal Alanlar ana sınıfına, \%1,5'ini oluşturan 5,8 km²'si “4” ana kodlu Islak Alanlar ana sınıfina dönüşmüştür. Arazi değişim matrisi 1990 ve 2018 yılları mukayesesine göre İlde "2" ana kodlu Tarım Alanları lehine $291 \mathrm{~km}^{2}$ kazanç meydana gelmiştir (Şekil 7).

CORINE arazi örtüsü/arazi kullanımı verilerine göre. "2" ana kodlu Tarım arazileri sınıfında pozitif yönlü en önemli değişiklik "231" alt kodlu Mera arazilerinde meydana gelmiştir. $\mathrm{Bu}$ arazi sınıfı 1990 yılında $1164 \mathrm{~km}^{2}$ yüzölçümle ildeki tüm arazilerin \%11,40'1nı oluştururken, 2018 yılına kadar geçen 30 yıllık süreç sonunda \%31 artışla İl arazilerinin \%15'ini oluşturan $1529 \mathrm{~km}^{2}$ alana ulaşmıştır (Şekil 5). İlde bu alt sınıftaki arazi miktarındaki artışın kırsal yerleşimlerde sürdürülen hayvancılık üretimine besin girdisi sağlamak amaciyla özellikle " 3 " ana kodlu Orman ve Yarı Doğal Alanların bu sınıf arazilerine dönüştürülmesinden kaynaklandığı anlaşılmaktadır. İlde bahsi geçen alanlarda büyük ve küçükbaş hayvan varlığında son y1llarda meydan gelen artış bu durumu teyit etmektedir.

CORINE verilerine göre 1990 yılından 2018 yılına kadar geçen süreçte "2" ana kodlu Tarım Alanları genel gurubunda en önemli negatif değişim "243” alt kodlu Doğal Bitki Örtüsü ile Bir Arada Bulunan Tarım Alanları alt sınıfinda meydana gelmiştir. Bu alt sınıftaki araziler 1990 yılında $901 \mathrm{~km}^{2}$ yüzölçümle ildeki tüm arazilerin \%8,83'ünü oluştururken 2018 yılına kadar geçen süreçte $\% 8$ azalışla İl arazi varlığının \%8,13'ünü oluşturan 829,3 $\mathrm{km}^{2}$ alana gerilemiştir. Arazi değişim matrisi bu gruptaki arazilerin negatif yönlü seyrinin bu arazilerin büyük kısmının hayvancılık üretimine besin girdisi sağlamak amacıyla "2" ana kodlu Tarım Arazilerine dönüştürülmesinden kaynaklandığg göstermektedir (Şekil 7).

\subsection{3. "3” Orman ve Yarı Doğal Alanlar}

CORINE arazi örtüsü/arazi sinıflandırmasına göre Kars ilinde "3" ana kodlu Orman ve Yarı Doğal alanlar sınıfindaki arazilerin önemli kısmı irtifa ve eğim değerlerinin nüfus ve yerleşmeyi oldukça kısıtladığı, İl idari alanını batıdan çevreleyen Allahuekber Dağları, güneyden çevreleyen Aras Güneyi Dağları ve Aras Vadisi boyunca toplanmıştır (Şekil 5). İlde bu ana sınıfa dâhil araziler İl genelinin \%38,7'sine denk gelen $3.946 \mathrm{~km}^{2}$ yüzölçüme sahiptir.

Kars iline ait 1990 ve 2018 y1lı CORINE arazi örtüsü/ kullanımı veri setleri kullanılarak yapılan karşılaştırma sonucunda İl arazilerindeki düzey " 1 "sınıfindaki en önemli negatif değişiklik "3” ana kodlu Orman ve Yarı Doğal alanlar sınıfinda meydana gelmiştir. Bu gruba dâhil arazilerin 1990 yllında toplam alanı $4.310 \mathrm{~km}^{2}$ ile İl genel arazisinin \%42.3'ünü oluştururken 2018 yılı itibariyle bu arazi gurubunun genel alanı \%8.4 azalarak İl genel alanının \%38,7'sine denk gelen 3.946 $\mathrm{km}^{2}$ ' ye gerilemiştir (Şekil 4, Şekil 5).

CORINE arazi örtüsü/kullanımı verileri değişim matrisi verilerine göre "3" ana kodlu Orman ve Yarı Doğal alanlar ana sınıfında toplam $3644 \mathrm{~km}^{2}$ arazi bu ana sınıfın kendi içindeki alt arazi sınıflara dönüşmüştür. Diğer ana arazi sınıflarına dönüşen toplam $664 \mathrm{~km}^{2}$ arazinin \%0,9'unu oluşturan 6,3 $\mathrm{km}^{2}$ 'si "1" ana kodlu Yapay Yüzeyler ana sınıfına, \%98,9'unu oluşturan 657 $\mathrm{km}^{2}$ 'si "2" ana kodlu Tarım Alanları ana sinıfina, \%0,1'ini oluşturan 0,058 km²'si "4" ana kodlu Islak Alanlar ana sınıfına, $\% 0,1$ 'ini oluşturan $0,63 \mathrm{~km}^{2}$ 'si " 5 " ana kodlu Su Toplulukları ana sınıfına, dönüşmüştür (Şekil 7).

İlde "3" ana kodlu Orman ve Yarı Doğal alanlar sınıfındaki arazilere dönüsşen diğer ana arazi sınıflarına ait toplam $302 \mathrm{~km}^{2}$ arazinin, \%1'ini oluşturan 3,28 km²'si "1" ana kodlu Yapay Yüzeyler ana sınıfindan, \%98,6'sını oluşturan 298 km²'si "2" ana kodlu Tarım Alanları ana sınıfindan, \%0,002'sini oluşturan $0,007 \mathrm{~km}^{2}$ 'si “4” ana kodlu Islak Alanlar ana sinıfindan \%0,2'sini oluşturan $0,8 \mathrm{~km}^{2}$ 'si " 5 " ana kodlu Su Toplulukları ana sınıfından dönüşmüştür. Arazi değişim matrisi 1990 ve 2018 yılları mukayesesine göre İlde "3" ana kodlu Orman ve Yarı Doğal alanlar sınıfı arazileri aleyhine $363 \mathrm{~km}^{2}$ kayıp meydana gelmiştir (Şekil 7). 
CORINE arazi örtüsü/arazi verileri göre Kars ilindeki "3" ana kodlu Orman ve Yarı Doğal alanlar sınıfındaki araziler içinde en önemli negatif arazi değişikliği doğal büyükbaş hayvancılık faaliyetleri için en önemli besin girdisi kaynağını oluşturan "321" alt kodlu doğal çayır alanları sınıfında meydana gelmiştir. 1990 yılında $2.209 \mathrm{~km}^{2}$ yüzölçümle İldeki tüm arazilerin \%21,67'sini oluşturan doğal çayırlık araziler, 2018 yılında \%13 azalışla İl arazi varlığının \%18.81'ni oluşturan $1.917 \mathrm{~km}^{2}$ alana gerilemiştir (Şekil 5). Bu alt sınıf arazilerindeki negatif değişimin büyük kısmının İlde hayvancılık üretiminde istikrarı sağlamak amaciyla bu arazilere yem bitkilerinin ekilmesi ve " 2 " ana kodlu Tarım Alanları arazi gurubundaki meralara dönüştürülmesinden kaynaklandığı anlaşılmaktadır.

"3" ana kodlu Orman ve Yarı Doğal Alanlar ana sinıfinda en çok dikkat çeken negatif değişimlerden biri genel olarak "311" kodlu Geniş Yapraklı Ormanlar, "312” kodlu Kozalaklı Ağaç Ormanlar, "313" kodlu Karışık Ormanlar alt sınıflarında meydana gelmiştir. Bu alt sınıfta büyük kısmı Sarıkamış ilçesi sınırları dâhilinde bulunan ve 1990 yılında 333,7 km² yüzölçümle İldeki tüm arazilerin \%3,27'sini oluşturan tüm Ormanlık Alanlar 2018 y1lında \%8,1 azalışla İl arazilerinin \%3,01'ini oluşturan $306,7 \mathrm{~km}^{2}$ alana gerilemiş̧ir (Şekil 5). İlin ormanlık alanlarında 1990 ve 2018 yılları arasındaki 30 yıllık sürede meydana gelen arazi kaybı Orman İşletmesi tarafından amenajman planları dâhilinde yapılan gençleştirme uygulamaları yanında, civar halkının yaptı̆̆ kaçak kesimlere dayanmaktadır (OGM. 2019). İlde arazi sınıfları arasındaki geçişimin tespit edilmesi amacıyla oluşturulan değişim matrisi bu alt sınıftaki $35,30 \mathrm{~km}^{2}$ arazinin \%96'sının büyük kısmı Geçici Orman-Çalılık alt sınıfına ait olmak üzere "3" Ana kodlu Orman ve Doğal arazilere dönüştüğünü göstermektedir (Şekil 7).

\subsection{4. "4” Islak Yüzeyli Alanlar}

CORINE verilerine göre Kars İlinde "4" ana kodlu Islak Yüzeyli Alanlar genel sınıfındaki arazilerin büyük kısmı Çıldır, Aygır, Kuyucuk gölleri, Arpaçay Baraj Gölü ve Aras Nehri kıyı

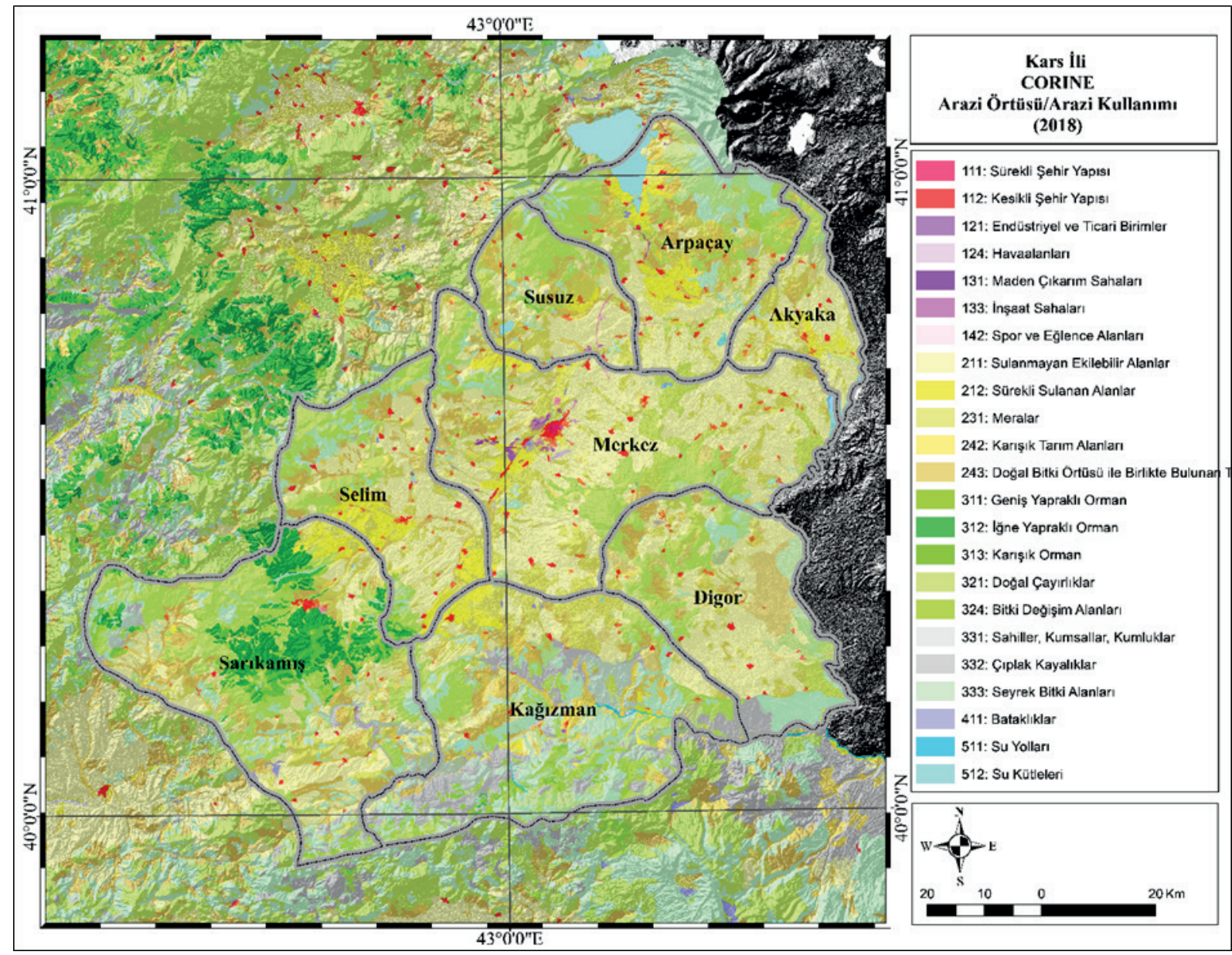

Şekil 4: CORINE "düzey 3" sınıflandırmasına göre Kars illinde Arazi Örtüsü/Arazi Kullanımı Dağılımı (2018). Figure 4: Distribution of Land Cover in Kars Province According to CORINE "level 3" Classification (2018). 


\begin{tabular}{|c|c|c|c|c|c|c|c|c|c|c|c|}
\hline \multirow{2}{*}{ Kodu } & \multirow{2}{*}{ Arazi Örtüsü/ Kullanıııı Sintitı } & \multirow{2}{*}{ Kodu } & \multirow{2}{*}{ Arazi Örtüsü/Arazi Kullanımı Sınıfı } & \multicolumn{2}{|c|}{ Arazi. Ört/Arz.Kul.(2018) } & \multicolumn{2}{|c|}{ Arazi. Ört/Arz.Kul.(2040) } & \multicolumn{2}{|c|}{ Arazi Kullanım (2018-2040) } & \multicolumn{2}{|c|}{ Arazi Kullanım (2018-2040) } \\
\hline & & & & Alanı $(\mathrm{km} 2$ & Oran (\%) & Alanı (km2) & Oran $(\%)$ & Farkı $(\mathrm{Km} 2$ & Değişimi (\%) & Farkı (Km2 & Değişimi (\%) \\
\hline \multirow{7}{*}{1} & \multirow{7}{*}{ Yapay Yüzeyler } & 111 & Devamlı şehir yapısı & 2,87 & $0,03 \%$ & 2,86 & $0,03 \%$ & $-0,02$ & $0, \phi 0 \%$ & \multirow{7}{*}{63,1} & \multirow{7}{*}{$4,8 \%$} \\
\hline & & 112 & Devamlı olmayan şehir yapısı & 84,55 & $0,82 \%$ & 120,09 & $1,18 \%$ & 35,54 & $2,2 \%$ & & \\
\hline & & 121 & Endüstriyel veya ticari birimler & 2,10 & $0,02 \%$ & 13,81 & $0,14 \%$ & 11,71 & $1, \phi 4 \%$ & & \\
\hline & & 124 & Hava alanları & 2,12 & $0,02 \%$ & 2,85 & $0,03 \%$ & 0,73 & $0, \phi 6 \%$ & & \\
\hline & & 131 & Maden çıkarım alanları & 2,29 & $0,02 \%$ & 9,80 & $0,10 \%$ & 7,51 & $0, \$ 7 \%$ & & \\
\hline & & 133 & İnşaat sahaları & 1,10 & $0,02 \%$ & 8,63 & $0,08 \%$ & 7,53 & $0,43 \%$ & & \\
\hline & & 142 & Spor Ve Dinlenme Alanları & 1,50 & $0,01 \%$ & 1,57 & $0,02 \%$ & 0,07 & $0,01 \%$ & & \\
\hline \multirow{5}{*}{2} & \multirow{5}{*}{ Tarım Alanları } & 211 & Sulanmayan tarımsal araziler & $2.983,4$ & $29,28 \%$ & $2.908,0$ & $28,52 \%$ & $-75,44$ & $-5,3 \%$ & \multirow{5}{*}{586,4} & \multirow{5}{*}{$44,7 \%$} \\
\hline & & 212 & Sürekli sulanan araziler & 383,8 & $3,77 \%$ & 401,3 & $3,94 \%$ & 17,43 & $1,33 \%$ & & \\
\hline & & 231 & Meralar & $1.164,0$ & $11,40 \%$ & $1.529,2$ & $15,00 \%$ & 365,22 & $27,85 \%$ & & \\
\hline & & 242 & Karışık tarım alanları & 260,4 & $2,54 \%$ & 316,7 & $3,11 \%$ & 56,31 & $4,26 \%$ & & \\
\hline & & 243 & Doğal bitki örtüsü ile birlikte tarım alanları & 901,3 & $8,83 \%$ & 829,3 & $\$, 13 \%$ & $-71,99$ & $-5,50 \%$ & & \\
\hline \multirow{8}{*}{3} & \multirow{8}{*}{ Orman ve Yarı Doğal Alanlar } & 311 & Geniş yapraklı ormanlar & 4,56 & $0,05 \%$ & 3,5 & $0,03 \%$ & $-1,09$ & $-0,08 \%$ & \multirow{8}{*}{649,9} & \multirow{8}{*}{$49,6 \%$} \\
\hline & & 312 & Kozalaklı ağaç ormanlar & 268,2 & $2,63 \%$ & 261,2 & $2,56 \%$ & $-7,02$ & $-0,54 \%$ & & \\
\hline & & 313 & Karışsı ormanlar & 60,9 & $0,59 \%$ & 42,0 & $0,41 \%$ & $-18,95$ & $-1 / 45 \%$ & & \\
\hline & & 321 & Doğal çayırlıklar & 2208,7 & $21,67 \%$ & 1917,1 & $18,80 \%$ & $-291,66$ & $-22,28 \%$ & & \\
\hline & & 324 & Geçici orman- çalılık & 160,7 & $1,57 \%$ & 171,50 & $1,68 \%$ & 10,79 & $0, \$ 2 \%$ & & \\
\hline & & 331 & Sahiller, kumsallar ve kum düzlükleri & 6,83 & $0,07 \%$ & 6,8 & $0,07 \%$ & 0,00 & $0,00 \%$ & & \\
\hline & & 332 & Çıplak kayalık & 361,1 & $3,54 \%$ & 493,4 & $4,84 \%$ & 132,30 & $10,11 \%$ & & \\
\hline & & 333 & Seyrek bitkili alanlar & 1238,6 & $12,15 \%$ & 1051 & $10,30 \%$ & $-188,07$ & $-14,35 \%$ & & \\
\hline 4 & Islak Alanlar & 411 & liç bataklıklar & 17,83 & $0,17 \%$ & 17,0 & $0,17 \%$ & $-0,79$ & $-0,06 \%$ & 0,8 & $0,1 \%$ \\
\hline \multirow{2}{*}{5} & \multirow{2}{*}{ Su Toplulukları } & 511 & Suyolları & 8,08 & $0,08 \%$ & 7,7 & $0,08 \%$ & $-0,36$ & $-0,03 \%$ & \multirow{2}{*}{10,6} & \multirow{2}{*}{$1 \%$} \\
\hline & & 512 & Su kütleleri & 70,83 & $0,69 \%$ & 81,1 & $0,80 \%$ & 10,24 & $0,78 \%$ & & \\
\hline \multicolumn{4}{|r|}{ Toplam } & 10.196 & $100 \%$ & 10.196 & $100 \%$ & 0,00 & $100 \%$ & 1311 & $12,86 \%$ \\
\hline
\end{tabular}

Şekil 5: CORINE Sınıflandırmasına Göre Kars İlinin Arazi Kullanımı/Arazi Örtüsü Değişim Farkı (1990-2018).

Figure 5: Land Use/Land Cover Change Difference in Kars Province CORINE Classification (1990-2018).

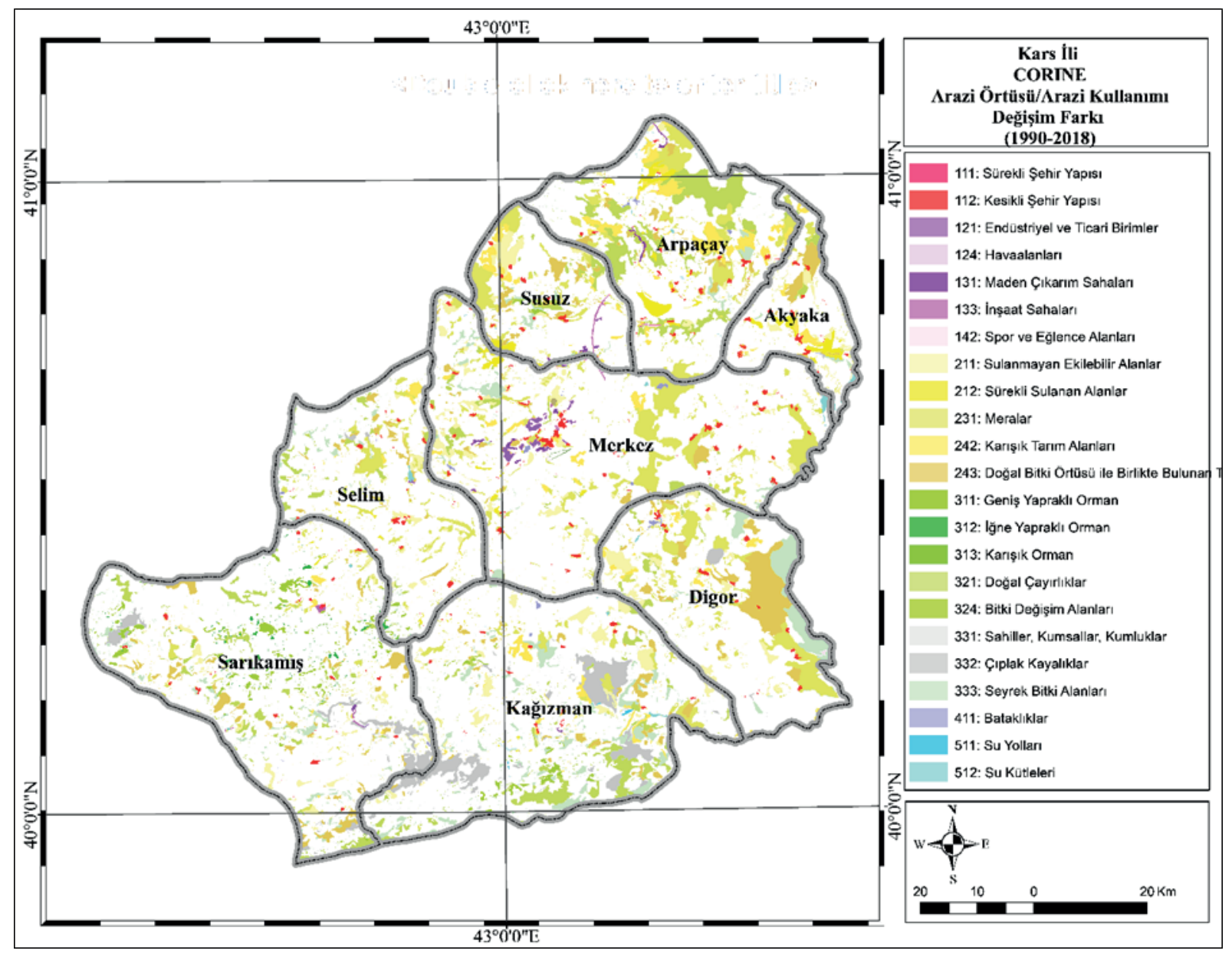

Şekil 6: CORINE sınıflandırmasına göre Kars İlinin Arazi Kullanımı/Arazi Örtüsü Değişim Farkı (1990-2018).

Figure 6: Distribution of Land Use / Land Cover Change Difference in Kars Province According to CORINE Classification (1990-2018). 


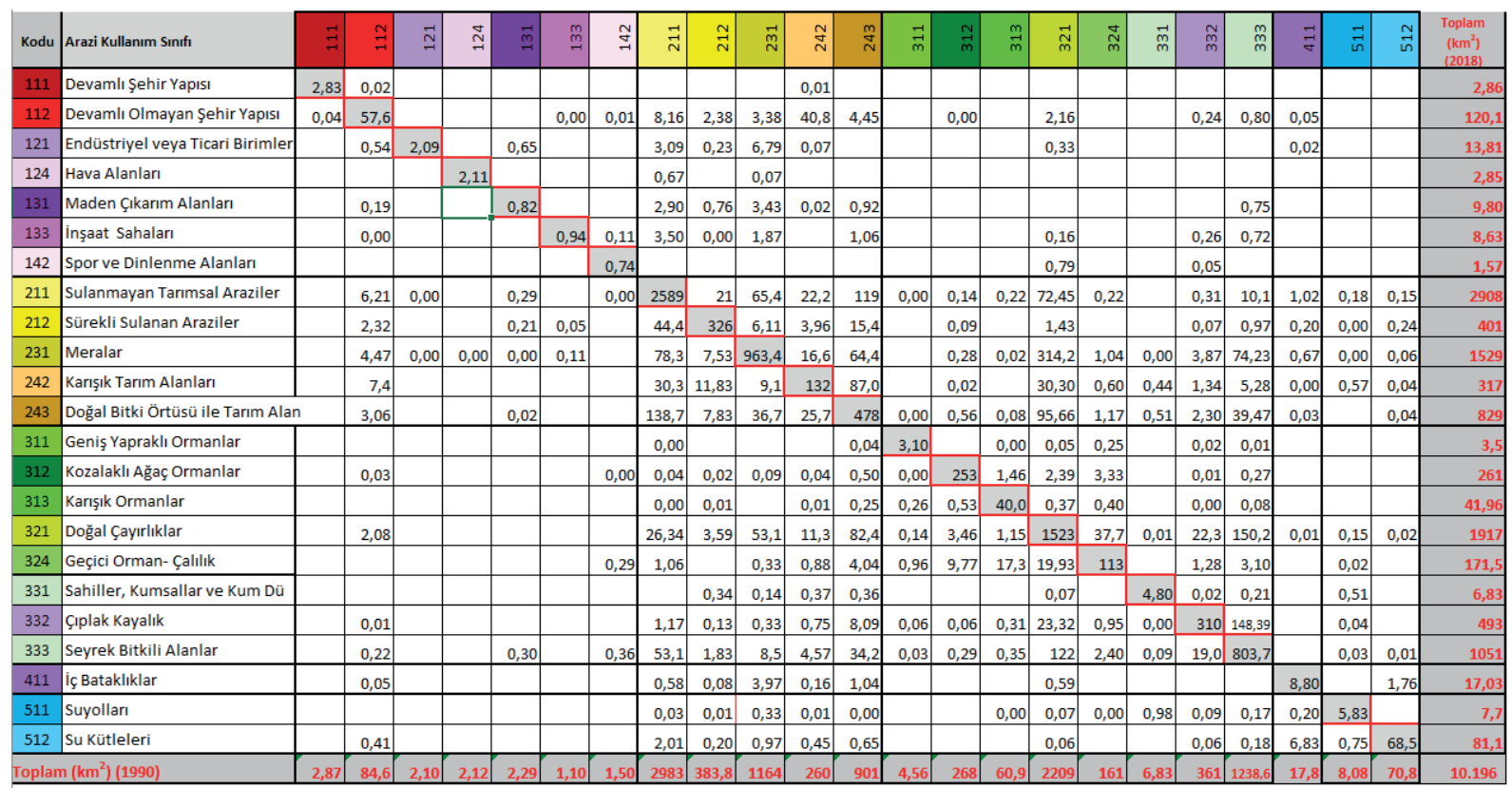

Şekil 7: CORINE Sınıflandırmasına göre Kars İlinin Arazi Örtüsü Değişim Matrisi (1990-2018).

Figure 7: Land Use / Land Cover Change Matrix of Kars Province According to CORINE "level 3" Classification (1990-2018).

alanlarında bulunmakta olup bu araziler kısmen sazlık bataklık özellik göstermektedir. İldeki tüm 1slak, bataklık araziler İl yüzölçümünün \%0,16'sını oluşturan $17,0 \mathrm{~km}^{2}$ alana sahiptir (Şekil 7).

CORINE verilerine göre "411” kodlu Bataklık Araziler 1990 yılında 17,83 km² yüzölçümle İl genelinin \%0,17'sini örterken, 2018 yılında bu araziler \%4 azalışla İlin \%0,16'sını oluşturan $17,0 \mathrm{~km}^{2}$ alana gerilemiştir (Şekil 6). Bataklık özellikteki alanlarda meydana gelen negatif değişimin bir kısmı Aras Nehri yatağında hidroelektrik santrallerin inşası nedeniyle meydana gelirken, diğer bir kısmı ise bu özellikteki alanların klimatik nedenlerle kuruyup/kurutulup özellikle "2" ana kodlu tarım alanları sınıfina dönüşmesi veya dönüştürülmesinden kaynaklanmaktadır (Demir, 2018).

CORINE arazi örtüsü/kullanımı değişim matrisi verilerine göre "4" ana sınıf kodlu Islak Yüzeyli Alanlar ana sınıfı arazileri içinde toplam $8,8 \mathrm{~km}^{2}$ arazi bu ana sınıfın kendi içindeki alt arazi sınıflarına dönüşmüştür. İlde "4" ana sınıf kodlu Islak Yüzeyli alanlarından diğer ana arazi sınıflarına dönüşen toplam $9 \mathrm{~km}^{2}$ arazinin \%0,8'ini oluşturan 0,07 km²'si "1" ana kodlu Yapay Yüzeyler ana sınıfına, \%21,2'sini oluşturan 1,92 km²'si "2" ana kodlu Tarım Alanları ana sınıfına, \%0,1'ini oluşturan 0,068 $\mathrm{km}^{2}$ 'si "3" ana kodlu Orman ve Yarı Doğal Alanlar ana sınıfına, \%77,9'unu oluşturan 7 km²'si "5" ana kodlu Su Toplulukları ana sınıfina, dönüşmüştür (Şekil 7).
İlde "4" ana sinıf kodlu Islak Yüzeyli Alanlar arazilerine dönüşen diğer ana arazi sınıflarına ait toplam $8,24 \mathrm{~km}^{2}$ arazinin, $\% 0,06$ 'sını oluşturan $0,05 \mathrm{~km}^{2}$ 'si "1" ana kodlu Yapay Yüzeyler ana sınıfindan, \%70,9'unu oluşturan 5,84 km²'si "2" ana kodlu Tarım Alanları ana sınıfından, \%7,1'ini oluşturan 0,58 km²'si "3" ana kodlu Orman ve Yarı Doğal Alanlar ana sınıfindan, \%21'ünü oluşturan 1,76 km²'si "5" ana kodlu Su Toplulukları ana sınıfından, Islak Alanlar ana sınıfından dönüşmüştür. Arazi değişim matrisi 1990 ve 2018 yılları mukayesesine göre İlde "1" ana sınıf kodlu Yapay Yüzeyler arazileri lehine $0,79 \mathrm{~km}^{2}$ kayıp meydana gelmiştir (Şekil 7).

\subsection{5. "5" Su Toplulukları}

CORINE arazi örtüsü/arazi kullanım verilerine göre Kars ilinde "5" ana kodlu Su Toplulukları genel sınıfindaki araziler İl arazi varlığının \%0,9'una denk gelen $89 \mathrm{~km}^{2}$ yüzölçüme sahiptir. İlde bu ana arazi sınıfı dâhilinde "511" kodlu akarsu, çay ve dereleri kapsayan Suyolları alt sınıfindaki arazilerin büyük kısmını Aras ve Arpaçay nehirleri oluştururken, "512" alt kodlu Su Kütleleri sınıfında arazilerin çok büyük kısmı ise Çıldır, Aygır ve Kuyucuk gölleri ve Arpaçay Baraj Gölü alanında bulunmaktadır (Şekil 7).

CORINE arazi kullanım verilerine göre Kars ilinde " 5 " ana kodlu Su Toplulukları genel sınıfına dâhil arazilerin 1990 yılında toplam alanı 78,8 km² ile İl yüzölçümünün \% 0,8 'ini oluştururken, 
2018 yılı itibariyle bu arazi sınıfının genel alanı \%13 artarak İl genel alanının \%0,9'una denk gelen 89 km²'ye ulaşmıştır (Şekil 4, Şekil 5). CORINE 1990 yılı ile 2018 yıllı verileri karşılaştırması sonucunda "5" ana kodlu su toplulukları genel sınıfindaki akarsu alanlarında çok düşük oranda olsa da negatif yönlü azalama görülürken, doğal ve yapay göl veya gölet alanlarında ise düşük düzeyde de olsa artış görülmektedir. İlde su toplulukları genel sınıfındaki arazi değişiminin büyük kısmı enerji üretimi veya sulama amaciyla oluşturulan baraj gölleri veya klimatik sebeplere dayalı olarak su bilançosunda meydana gelen değişime dayanmaktadır.

CORINE arazi örtüsü/kullanımı verileri değişim matrisi verilerine göre " 5 " ana kodlu Su Toplulukları ana sınıfı arazileri içinde toplam $75 \mathrm{~km}^{2}$ arazi bu ana sınıfın kendi içindeki alt arazi sınıflarına dönüşmüştür. İlde "5" ana sınıf kodlu Su Toplulukları arazilerinden diğer ana arazi sınıflarına dönüşen toplam 3,83 $\mathrm{km}^{2}$ arazinin \%33,5'ini oluşturan 1,28 $\mathrm{km}^{2}$ 'si "2" ana kodlu Tarım Alanları ana sınıfına, \%20,6'sını oluşturan 0,78 km²'si “3”" ana kodlu Orman ve Yarı Doğal Alanlar ana sınıfına, \%46'sını oluşturan 1,76 km²'si "4" ana kodlu Islak Alanlar ana sınıfina dönüşmüştür (Şekil 7).

İlde "5" ana sınıf kodlu Su Toplulukları arazilerine dönüşen diğer ana arazi sınıflarına ait toplam $12,7 \mathrm{~km}^{2}$ arazinin \%3,2'sini oluşturan 0,4 km²'si " 1 " ana kodlu Yapay Yüzeyler ana sınıfindan, \%36,6'sını oluşturan 4,66 km²'si "2" ana kodlu Tarım Alanları ana sinıfindan, \%4,9'unu oluşturan 0,063 km²'si "3" ana kodlu Orman ve Yarı Doğal Alanlar ana sınıfından, \%55,3'ünü oluşturan 7,03 km²'si "4" ana kodlu Islak Alanlar ana sınıfından dönüşmüştür. Arazi değişim matrisi 1990 ve 2018 yılları mukayesesine göre İlde " 5 " ana sınıf kodlu Su toplulukları arazileri lehine $8,9 \mathrm{~km}^{2}$ kazanç meydana gelmiştir (Şekil 7).

\subsection{Arazi Örtüsü/Arazi Kullanımı Projeksiyonu}

CORINE 1990 ve 2018 yılları verileri temel alınarak Kars ilindeki arazi örtüsü/arazi kullanımının 2040 yılındaki durumunun projeksiyone edilmesi amaciyla CA Markov yöntemiyle analizler yapılmıştır. Kars ilinde 1990-2018 yılları değerlendirme aralığındaki arazi örtüsü ve arazi kullanımında meydana gelen değişimleri etkileyen koşulların benzerlik göstermesi halinde projeksiyone edilen 2040 y1lında arazi örtüsü ve arazi kullanımın son örneklem yılı olarak alınan 2018 yılına göre toplam $1029 \mathrm{~km}^{2}$ değişim gösterebileceği anlaşılmaktadır.

Yerel, doğal ve beşeri koşulların baskın ve zorlayıcı etkisiyle hayvancılık ve tarım faaliyetlerinin ön plana çıktığ ilde ekonomik gelişim hızının düşük olmasına rağmen projeksiyone edilen 2040 yılı için genel arazi sınıflarının alanlarında önemli oranda değişim beklenmektedir. Kars ilinde 2040 yılında, arazi örtüsünün; \%2,1'inin "1" ana kodlu Yapay Yüzeyler sınıfında, \%60,9'unun "2" ana kodlu Tarım Alanları sınıfında, \%35,9'unun "3" ana kodlu Orman ve Yarı Doğal alanları sınıfinda, \%0,16'sının "4" ana kodlu Islak alan sinıfinda \%0,9'unun ise "5" ana kodlu Su Toplulukları sınıfındaki arazilerden oluşabileceği projeksiyone edilmiştir (Şekil 8, Şekil 9, Şekil 10).

Kars ilinin 2040 yılında arazi örtüsü ve arazi kullanımı projeksiyonu genel olarak en düşük oranlı değişimlerden birinin yerleşim alanlarını ve alt sınıflarını kapsayan "1" ana kodlu yapay yüzeyler sınıfında meydana gelebileceğini göstermektedir. 2018 yılında $160 \mathrm{~km}^{2}$ yüzölçümle İl arazilerinin \%1,6'sını oluşturan yerleşim alanlarını ve eklerini kapsayan "1" ana kodlu Yapay Yüzeyler gurubunun 2040 yılında \%31 artışla İl in $\% 2,1$ 'ine denk gelen $209 \mathrm{~km}^{2}$ ye ulaşabileceğini göstermektedir (Şekil 8, Şekil 9, Şekil 10). İlde başta Kars Merkez, Sarıkamış ve Kağızman gibi kentsel niteliklere sahip yerleşim alanlarına doğru meydana gelen göçlerin artı̧̧ eğilimi göstermesi ve bu durum sonucunda yerleşim alanlarının yatay ve dikey yönlü gelişim eğilimi nedeniyle "1" ana kodlu Yapay Yüzeyler ana sınıfındaki arazi artışının projeksiyona uygun olarak devam edebileceğini göstermektedir.

Kars ilinin 2040 yılında arazi örtüsü ve arazi kullanımı projeksiyonu, 2018 y1lında $5984 \mathrm{~km}^{2}$ yüzölçümle İl arazilerinin \%58,7'sni oluşturan "2" ana kodlu Tarım arazilerinin 2040 yılında \%4 artışla İl arazilerinin \%60,9'una denk gelen 6213 km² ye ulaşabileceğini göstermektedir (Şekil 8, Şekil 9, Şekil 10). Bu artış üzerinde;

- İlde veraset yoluyla bölünmüş olup tarımsal üretimde kullanılmayan ve vasfi değişmiş arazilerin T.C. Tarım ve Orman Bakanlığ girişimiyle son yıllarda arazi toplulaştırma çalışmalarıyla tekrar üretime kazandırılması çalışmalarının sürdürülmesi (Tarım ve Orman Bakanlığı, 2019),

- 5403 sayılı Toprak Koruma ve Arazi Kullanımı Kanunu hükümlerince tarım alanlarının tarım dışındaki kullanımlara tahsis edilmesinin engellenmesi (Tarım ve Orman Bakanlığı, 2019),

- İlin tanımlayıcı unsurlarından olan hayvancılık üretiminin geliştirilmesine yönelik olarak t T.C. Tarım ve Orman Bakanlığı tarafından yem bitkileri ve tahıl tarımının desteklenerek teşvik edilmesi (Tarım ve Orman Bakanlığı, 2019), 
gibi faktörlerin etkili olabileceği düşünülmektedir.

Kars ilinin 2040 yılında arazi örtüsü ve arazi kullanımı

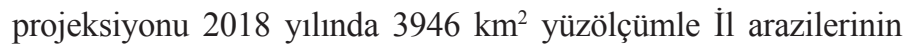
\%38,7'sini oluşturan “3” ana kodlu Orman ve Yarı Doğal arazilerin 2040 yılında \%7 azalışla İl arazilerinin \%35,9'una denk gelen 3660 km² yüzölçüme gerileyebileceğini göstermektedir (Şekil 9, Şekil 10). 2872 sayılı Çevre Kanunu hükümlerine tabi olan bu gruptaki arazilerin ilgili çevre kanunu hükümlerinin katı şekilde uygulanması halinde projeksiyon hesaplamasından elde edilen sonuca paralel olarak düşük oranlı ve anlamlı olmayan negatif değişimin gösterebileceği anlaşılmaktadır.

Kars ilinin 2040 yılında arazi örtüsü ve arazi kullanımı projeksiyonu 2018 yılında $17 \mathrm{~km}^{2}$ yüzölçümle İl arazilerinin \%0,17'sini oluşturan "4” ana kodlu Islak Arazilerin 2040 yılına kadar \%3,6 azalışla İl arazilerinin \%0,16'sına denk gelen 16,4 $\mathrm{km}^{2}$ 'ye gerileyebileceğini göstermektedir (Şekil 9, Şekil 10). İlde 2000 yılından itibaren kamu ve özel sektör tarafindan akarsular ve sulak alanlar üzerinde yapılan sulama ve elektrik enerjisi üretimine yönelik yatırımların etkisiyle yapısı değişim gösteren bu grup üyelerinin kullanım alanının aynı amaca yönelik olarak yapılan projelerin artış eğilimi göstermesi nedeniyle mevcut projeksiyondan da elde edilen sonuca aykırı şekilde artış gösterebileceği değerlendirilmektedir.

Kars ilinin 2040 yılında arazi örtüsü ve arazi kullanımı projeksiyonu 2018 yılında $89 \mathrm{~km}^{2}$ alanla İl arazilerinin \%0,9'unu oluşturan " 5 " ana kodlu su topluluklarının 2040 yılına kadar \%9 artışla İl arazilerinin \%0,96'sına denk gelen $96,6 \mathrm{~km}^{2}$ ye çıkacağını göstermektedir (Şekil 9, Şekil 10). İlde 2000 yılından itibaren kamu ve özel sektör tarafından akarsular ve sulak alanlar üzerinde yapılan sulama ve elektrik enerjisi üretimine yönelik yatırımların etkisiyle yapısı değişim gösteren bu grup üyelerinin kullanım alanının aynı amaca yönelik olarak yapılan projelerin artış eğilimi göstermesi nedeniyle mevcut projeksiyondan da elde edilen sonuca paralel şekilde artış gösterebileceği düşünülmektedir.

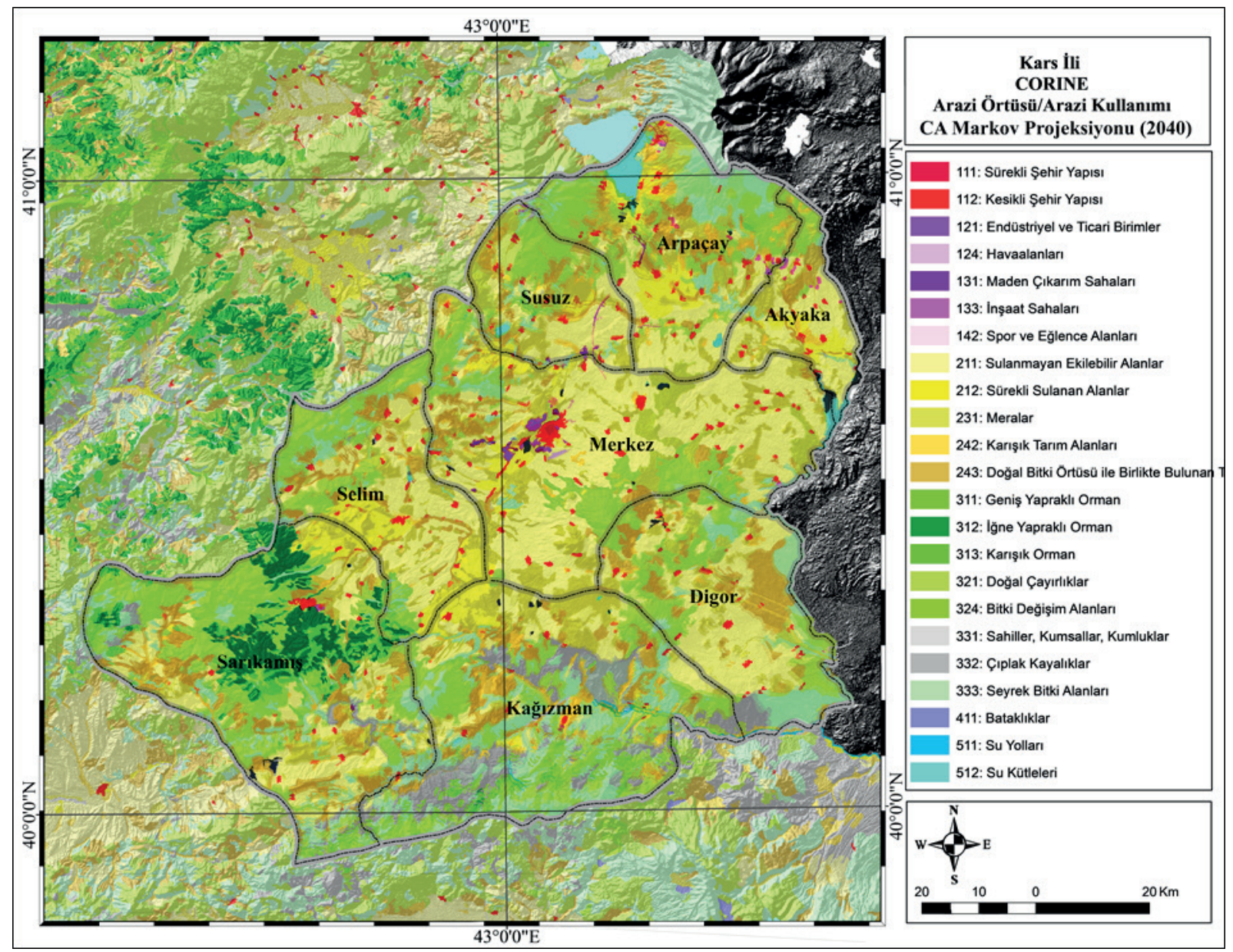

Şekil 8: CA Markov Projeksiyonuna göre CORINE "düzey 3" Kars illi Arazi Örtüsü/Arazi Kullanımı Dağılımı.

Figure 8: CORINE "level 3" Kars Province Land Cover / Land Use Distribution According to CA Markov Projection (2040). 


\begin{tabular}{|c|c|c|c|c|c|c|c|c|c|c|c|}
\hline \multirow{2}{*}{ Kodu } & \multirow{2}{*}{ Arazi Örtüsū/ Kullanımı Sınıfı } & \multirow{2}{*}{ Arazi Sintin Kodu } & \multirow{2}{*}{ Arazi Örtüsü/Arazi Kullanımı Sınıfı } & \multicolumn{2}{|c|}{ Arazi. Ört/Arz.Kul.(2018) } & \multicolumn{2}{|c|}{ Arazi. Ört/Arz.Kul.(2040) } & \multicolumn{2}{|c|}{ Arazi Kullanım (2018-2040) } & \multicolumn{2}{|c|}{ Arazi Kullanım (2018-2040) } \\
\hline & & & & Alanı (km2) & Oran (\%) & Alanı (km2) & Oran (\%) & Farkı (Km2) & Değişimi (\%) & Farkı (Km2) & Değişimi (\%) \\
\hline \multirow{7}{*}{1} & \multirow{7}{*}{ Yapay Yüzeyler } & 111 & Devamlı şehir yapısı & 2,86 & $0,03 \%$ & 2,84 & $0,03 \%$ & $-0,01$ & $0,5 \%$ & \multirow{7}{*}{49,59} & \multirow{7}{*}{$4,8 \%$} \\
\hline & & 112 & Devamlı olmayan şehir yapısı & 120,09 & $1,18 \%$ & 148,0 & $1,45 \%$ & 27,93 & $23,3 \%$ & & \\
\hline & & 121 & Endüstriyel veya ticari birimler & 13,810 & $0,135 \%$ & 23,0 & $0,23 \%$ & 9,20 & $66,6 \%$ & & \\
\hline & & 124 & Hava alanları & 2,85 & $0,03 \%$ & 3,4 & $0,03 \%$ & 0,57 & $20,2 \%$ & & \\
\hline & & 131 & Maden çıkarım alanları & 9,80 & $0,10 \%$ & 15,7 & $0,15 \%$ & 5,90 & $60,2 \%$ & & \\
\hline & & 133 & İnşaat sahaları & 8,63 & $0,08 \%$ & 14,6 & $0,14 \%$ & 5,92 & $68,6 \%$ & & \\
\hline & & 142 & Spor ve Dinlenme Alanları & 1,57 & $0,02 \%$ & 1,6 & $0,02 \%$ & 0,06 & $3,6 \%$ & & \\
\hline \multirow{5}{*}{2} & \multirow{5}{*}{ Tarım Alanları } & 211 & Sulanmayan tarımsal araziler & $2.907,96$ & $28,52 \%$ & 2848,7 & $27,94 \%$ & $-59,27$ & $2,0 \%$ & \multirow{5}{*}{460,7} & \multirow{5}{*}{$44,8 \%$} \\
\hline & & 212 & Sürekli sulanan araziler & 401,25 & $3,94 \%$ & 414,9 & $4,07 \%$ & 13,69 & $3,4 \%$ & & \\
\hline & & 231 & Meralar & $1.529,19$ & $15,00 \%$ & 1816,1 & $17,81 \%$ & 286,96 & $18,8 \%$ & & \\
\hline & & 242 & Karışık tarım alanları & 316,74 & $3,11 \%$ & 361,0 & $3,54 \%$ & 44,24 & $1,4,0 \%$ & & \\
\hline & & 243 & Doğal bitki örtüsü ile birlikte tarım alanları & 829,32 & $\$, 13 \%$ & 772,8 & $7,58 \%$ & $-56,57$ & $\beta 6,8 \%$ & & \\
\hline \multirow{8}{*}{3} & \multirow{8}{*}{ Orman ve Yarı Doğal Alanlar } & 311 & Geniş yapraklı ormanlar & 3,5 & $0,03 \%$ & 2,6 & $0,03 \%$ & $-0,86$ & $-24,7 \%$ & \multirow{8}{*}{510,6} & \multirow{8}{*}{$49,6 \%$} \\
\hline & & 312 & Kozalaklı ağaç ormanlar & 261,2 & $2,56 \%$ & 255,7 & $2,51 \%$ & $-5,52$ & $2,1 \%$ & & \\
\hline & & 313 & Karışık ormanlar & 42,0 & $0,41 \%$ & 27,1 & $0,27 \%$ & $-14,89$ & $-35,5 \%$ & & \\
\hline & & 321 & Doğal çayırlıklar & 1917,1 & $18,80 \%$ & 1687,9 & $16,55 \%$ & $-229,16$ & $-12,0 \%$ & & \\
\hline & & 324 & Geçici orman- çalılık & 171,50 & $1,68 \%$ & 180,0 & $1,77 \%$ & 8,48 & $4,9 \%$ & & \\
\hline & & 331 & Sahiller, kumsallar ve kum düzlükleri & 6,83 & $0,07 \%$ & 6,8 & $0,07 \%$ & 0,00 & $0,0 \%$ & & \\
\hline & & 332 & Çıplak kayalık & 493,4 & $4,84 \%$ & 597,4 & $5,86 \%$ & 103,95 & $21,1 \%$ & & \\
\hline & & 333 & Seyrek bitkili alanlar & 1051 & $10,30 \%$ & 902,7 & $8,85 \%$ & $-147,77$ & $-14,1 \%$ & & \\
\hline 4 & Islak Alanlar & 411 & İç bataklıklar & 17,0 & $0,17 \%$ & 16,4 & $0,16 \%$ & $-0,62$ & $3,6 \%$ & $-0,62$ & $-0,1 \%$ \\
\hline \multirow{2}{*}{5} & \multirow{2}{*}{ Su Toplulukları } & 511 & Suyolları & 7,7 & $0,08 \%$ & 7,4 & $0,07 \%$ & $-0,28$ & $3,7 \%$ & \multirow{2}{*}{8,33} & \multirow{2}{*}{$1 \%$} \\
\hline & & 512 & Su kütleleri & 81,1 & $0,80 \%$ & 89,1 & $0,87 \%$ & 8,05 & $9 \%$ & & \\
\hline \multicolumn{4}{|c|}{ Toplam } & 10.196 & $100 \%$ & 10196 & $100 \%$ & 1029 & $0,0 \%$ & 1029 & $10,09 \%$ \\
\hline
\end{tabular}

Ş̧ekil 9: CA Markov Projeksiyonuna göre CORINE "düzey 3" Kars illi Arazi Örtüsü/Arazi Kullanımı (2040).

Figure 9: CORINE "level 3" Kars Province Land Cover/Land Use According to CA Markov Projection (2040).

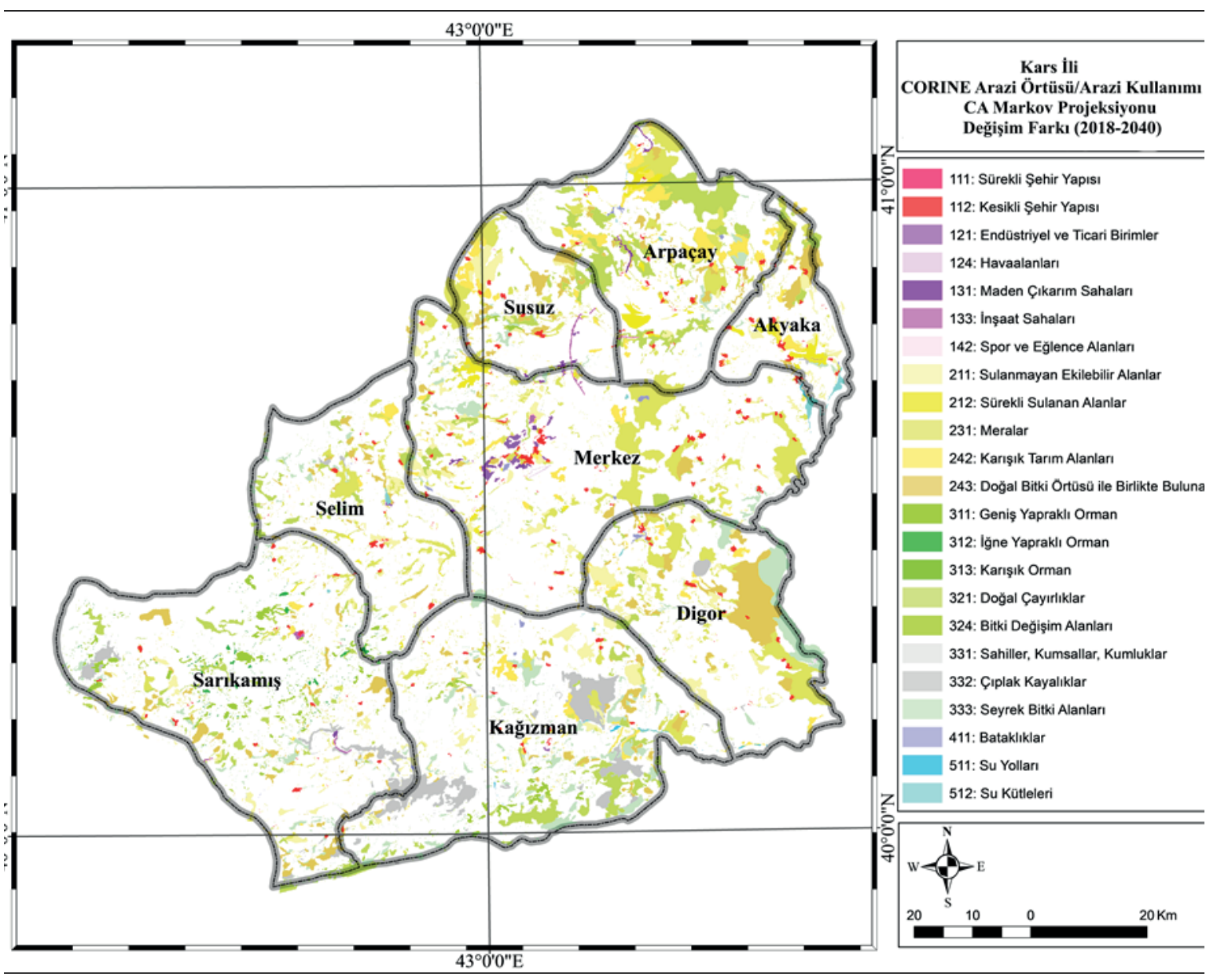

Şekil 10: CA Markov Projeksiyonuna göre CORINE "düzey 3" Sınıflandırması Kars İli Arazi Kullanımı/Arazi Örtüsü Değişim Farkı Dağılımı (2040). Figure 10: CORINE "level 3" Classification According to CA Markov Projection Kars Province Land Use / Land Cover Change Difference Distribution (2040). 


\begin{tabular}{|c|c|c|c|c|c|c|c|c|c|c|c|c|c|c|c|c|c|c|c|c|c|c|c|c|c|c|}
\hline Arazi Kullanım Sinff & Kodu & Arazi Kullanım Sinfif & $\exists$ & $\exists$ & ปี & $\underset{\pi}{\pi}$ & $\overrightarrow{\vec{m}}$ & 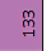 & f & $\vec{n}$ & สี & $\overrightarrow{\tilde{N}}$ & I & $\stackrel{m}{\sim}$ & $\overrightarrow{\mathrm{m}}$ & लै & $\begin{array}{l}m \\
\text { m }\end{array}$ & $\underset{m}{a}$ & 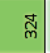 & $\overrightarrow{\mathrm{m}}$ & ల్m & m్ & $\exists$ & iี & $\stackrel{7}{\text { กิ }}$ & \begin{tabular}{|c|} 
Toplam $\left(\mathrm{km}^{2}\right)$ \\
$(2040)$
\end{tabular} \\
\hline \multirow{7}{*}{ 1.Yapay Yüzeyler } & 111 & Devamlı Şehir Yapısı & 2,83 & 0,03 & & & & & & & & & 0,01 & & & & & & & & & & & & & 2,87 \\
\hline & 112 & Devamlı Olmayan Şehir Yapısı & 0,03 & 57,6 & & & & 0,00 & 0,01 & 15,16 & 2,38 & 3,38 & 40,8 & 14,45 & & 0,00 & & 13,16 & & & 0,24 & 0,80 & 0,05 & & & 148,0 \\
\hline & 121 & Endüstriyel veya Ticari Birimler & & 0,54 & 2,09 & & 0,65 & & & 3,09 & 0,23 & 16,09 & 0,07 & & & & & 0,23 & & & & & 0,02 & & & 23,01 \\
\hline & 124 & Hava Alanları & & & & 2,11 & & & & 1,27 & & 0,07 & & & & & & & & & & & & & & 3,45 \\
\hline & 131 & Maden Çıkarım Alanları & & 0,19 & & & 0,82 & & & 2,90 & 0,76 & 9,43 & 0,02 & 0,92 & & & & & & & & 0,75 & & & & 15,80 \\
\hline & 133 & Inşaat Sahaları & & 0,00 & & & & 0,94 & 0,11 & 6,50 & \begin{tabular}{|r|}
0,00 \\
\end{tabular} & 4,87 & & 1,06 & & & & 0,16 & & & 0,26 & 0,72 & & & & 14,63 \\
\hline & 142 & Spor ve Dinlenme Alanları & & & & & & & 0,74 & & & & & & & & & 0,83 & & & 0,05 & & & & & 1,61 \\
\hline \multirow{5}{*}{ 2.Tarım Alanları } & 211 & Sulanmayan Tarımsal Araziler & & 6,21 & 0,00 & & 0,29 & & 0,00 & 2589 & 21 & 65,4 & 22,2 & 60 & 0,00 & 0,14 & 0,22 & 72,45 & 0,22 & & 0,31 & 10,1 & 1,02 & 0,18 & 0,15 & 2849 \\
\hline & 212 & Sürekli Sulanan Araziler & & 2,32 & & & 0,21 & 0,05 & & 44,4 & 326 & 6,11 & 3,96 & 28,4 & & 0,09 & & 1,43 & & & 0,07 & 0,97 & 0,20 & 0,00 & 0,24 & 414 \\
\hline & 231 & Meralar & & 4,47 & 0,00 & 0,00 & 0,00 & 0,11 & & 78,3 & 7,53 & \#\#\# & 16,6 & 64,4 & & 0,28 & 0,02 & 314,2 & 1,04 & 0,00 & 3,87 & 74,23 & 0,67 & 0,00 & 0,06 & 1816 \\
\hline & 242 & Karıı̧ık Tarım Alanları & & 7,4 & & & & & & 30,3 & 11,83 & 9,1 & 176 & 87,0 & & 0,02 & & 30,30 & 0,60 & 0,44 & 1,34 & 5,28 & 0,00 & \begin{tabular}{|l|}
0,57 \\
\end{tabular} & 0,04 & 361 \\
\hline & 243 & Doğal Bitki Örtüsü ile Tarım Alan & & 3,06 & & & 0,02 & & & 138,7 & 7,83 & 36,7 & 25,1 & 422 & 0,00 & 0,56 & 0,08 & 95,66 & 1,17 & 0,51 & 2,30 & 39,47 & 0,03 & & 0,04 & 773 \\
\hline \multirow{8}{*}{$\begin{array}{l}\text { 3.Orman ve } \\
\text { Yarı Doğal } \\
\text { Alanlar }\end{array}$} & 311 & Geniş Yapraklı Ormanlar & & & & & & & & 0,00 & & & & 0,04 & 2,27 & & 0,00 & 0,05 & 0,25 & & 0,02 & 0,01 & & & & 2,6 \\
\hline & 312 & Kozalaklı Ağaç Ormanlar & & 0,03 & & & & & 0,00 & 0,04 & 0,02 & 0,09 & 0,04 & 0,50 & 0,00 & 250 & 0,46 & 0,39 & 3,33 & & 0,01 & 0,27 & & & & 255 \\
\hline & 313 & Karı̧ıık Ormanlar & & & & & & & & 0,00 & 0,01 & & 0,01 & 0,25 & 0,26 & 0,53 & 25,0 & 0,37 & 0,40 & & 0,00 & 0,08 & & & & 26,96 \\
\hline & 321 & Doğal Çayırlıklar & & 2,08 & & & & & & 6,34 & 3,59 & 53,1 & 11,3 & 82,4 & 0,14 & 3,46 & 1,15 & 1339 & 12,7 & 0,01 & 22,3 & 150,2 & 0,01 & \begin{tabular}{|l|}
0,15 \\
\end{tabular} & 0,02 & 1688 \\
\hline & 324 & Geçici Orman-Çalılık & & & & & & & 0,29 & 1,06 & & 0,33 & 0,88 & 4,04 & 0,96 & 18,77 & 17,3 & 19,93 & 113 & & 1,28 & 3,10 & & 0,02 & & 180,5 \\
\hline & 331 & Sahiller, Kumsallar ve Kum Dü & & & & & & & & & 0,34 & 0,14 & 0,37 & 0,36 & & & & 0,07 & & 4,80 & 0,02 & 0,21 & & 0,51 & & 6,83 \\
\hline & 332 & Çıplak Kayalık & & 0,01 & & & & & & 1,17 & 0,13 & 0,33 & 0,75 & 8,09 & 0,06 & 0,06 & 0,31 & 123,32 & 0,95 & 0,00 & 310 & \#\#\#井 & & 0,04 & & 597 \\
\hline & 333 & Seyrek Bitkili Alanlar & & 0,22 & & & 0,30 & & 0,36 & 42,1 & 1,83 & 0,5 & 4,57 & 14,2 & 0,03 & 0,29 & 0,35 & 122 & 2,40 & 0,09 & 9,0 & 703,7 & & 0,03 & 0,01 & 902 \\
\hline 4.Islak Alanlar & 411 & iç̧ Bataklıklar & & 0,05 & & & & & & 0,58 & 0,08 & 3,88 & 0,16 & 1,04 & & & & 0,09 & & & & & 8,80 & & 1,76 & 16,44 \\
\hline \multirow{2}{*}{ 5.Su Topluluklar } & 511 & Suyolları & & & & & & & & 0,03 & 0,01 & 0,33 & 0,01 & 0,00 & & & 0,00 & 0,07 & 0,00 & 0,68 & 0,09 & 0,17 & 0,20 & 5,83 & & 7,4 \\
\hline & \begin{tabular}{|l|}
512 \\
\end{tabular} & Su Kütleleri & & 0,41 & & & & & & 2,01 & 0,20 & 0,97 & 0,45 & 0,65 & & & & 0,06 & & & 0,06 & 0,18 & 14,83 & 0,75 & 68,5 & 89,1 \\
\hline \multicolumn{3}{|c|}{ Toplam $\left(\mathrm{km}^{2}\right)(2018)$} & 2,86 & 120,05 & 13,81 & 2,85 & $9,80 \mid$ & 8,63 & 1,57 & $2007,96 \mid$ & $|401,25|_{1}$ & $|1529,18|$ & 316,74 & 829,32 & 3,47 & 261,09 & 41,96 & $|1916,93|$ & 171,50 | & 6,83 & $493,43 \mid$ & |1050,50| & $\mid 17,03$ & 7,72 & 81,07 & 10.194 \\
\hline
\end{tabular}

Şekil 11: CORINE Sınıflandırmasına göre Kars İlinin Arazi Örtüsü Değişim Matrisi (1990-2018).

Figure 11: Land Use / Land Cover Change Matrix of Kars Province According to CORINE "level 3" Classification (1990-2018).

\section{SONUÇ VE ÖNERILER}

CORINE 2018 yılı veri seti kullanılarak yapılan analizlere göre 10196 km² yüzölçümüne sahip Kars ilinde, 5 ana arazi örtüsü/arazi kullanım sınıfındaki 23 arazi alt sınıfına ait arazi bulunmaktadır. İldeki arazi örtüsünün \%2'sini oluşturan 160 km²'si "1"ana kodlu Yapay Yüzeyler genel sınıfında, \%59'unu oluşturan 3984 km²'si “2”ana kodlu Tarım Alanları genel sinıfinda, \%39'unu oluşturan 3946 km²'si “3” "ana kodlu Orman ve Yarı Doğal Alanlar genel sınıfında, \%0,2'sini oluşturan 17 km²'si “"'ana kodlu Islak Alanlar genel sınıfında, \%1'ini oluşturan $89 \mathrm{~km}^{2}$ 'si "5"ana kodlu $\mathrm{Su}$ toplulukları genel sinıfinda bulunmaktadir.

CORINE arazi örtüsü/arazi kullanım sinıflamasına göre Kars ilinde 1990 yılından 2018 yılına kadar geçen 28 y1llık süreçte Düzey "1" ana sınıfında en önemli oransal değişiklik "1" sınıf kodlu Yapay Yüzeyler genel sınıfinda meydana gelmiştir. Yerleşim alanları ve çevrelerindeki yapılar ve altyapı unsurlarını kapsayan bu ana sınıfa dâhil arazilerin 1990 yılında toplam alanı $96,5 \mathrm{~km}^{2}$ ile İl genel alanının \%0,98'unu oluştururken, 2018 yılı itibariyle bu arazi grubunun genel alanı $\% 65,8$ artarak İl genel alanının \%1,6'sına denk gelen 160 km² ye ulaşmıştır. İlde beşeri faaliyetlerin yürütüldüğü bu grup arazilerinin pozitif yönlü genel değişim oranının oldukça yüksek olması İl dışına giden nüfus göçlerinin olumsuz etkilerine rağmen çoğunlukla kamu yatırımlarına dayalı olarak meydana gelen ekonomik gelişime dayanmaktadır. İlde "1" sınıf kodlu Yapay Yüzeyler ana sınıfına
Tarım arazileri, Orman ve Yarı doğal arazi gruplarından dönüşüm oranının fazlalığı nedeniyle Tarımsal üretim alanları ve doğal çevre unsurları önemli oranda zarar görmektedir. Bu alanların korunması ve başta yerleşim unsurlarına ait yatay yönlü gelişimin sınırlandırılması gerekmekte olup bu amaçla ilgili kanunlara dayalı koruma hükümlerinin başta belediyeler ve il özel idaresi birimleri tarafından katı ve tavizsiz şekilde uygulanması gerekmektedir.

Kars iline ait 1990 ve 2018 y1lı CORINE verileri kullanılarak oluşturulan değişim matrisine göre yapılan karşılaştırmalar İl yüzölçümünün \%12,84'üne denk gelen toplam $1310 \mathrm{~km}^{2}$ alanda arazi örtüsü/arazi kullanımı değişim meydana geldiğini göstermektedir. İldeki arazi örtüsü/arazi kullanımı değişiminin \%44,7'sine denk gelen 586,4 km²'si "2" ana kodlu Tarım Alanları sinıfinda, \%49,6'sina denk gelen 649,9 km²'si "3" ana kodlu Orman ve Yarı doğal Alanlar sınıfında meydana gelmiş̧tir. Bu sonuçlara göre İldeki arazi örtüsü/arazi kullanımı değişimin neredeyse tamama yakın kısmı "2" ana kodlu Tarım Arazileri ve "3" ana kodlu Orman ve Yarı Doğal alan arazi gruplarında meydana gelmiş olup bu durum beşeri müdahalelerin arazi örtüsü üzerinde baskın etkisini göstermektedir. Ekonomik bakımdan hayvancılık ve tarım faaliyetlerinin baskın olduğu Kars ilinde diğer arazi gruplarından hayvancılık ve tarım alanında kullanılan arazilere dönüşüm oranının fazlalığı nedeniyle İldeki doğal çevre üzerinde kalıcı ve olumsuz değişiklikler meydana getirmektedir. $\mathrm{Bu}$ olumsuzlukların önlenmesi için ilgili devlet kuruluşları tarafından 5403 sayılı 
Toprak Koruma ve Arazi Kullanımı Kanunu ve 2872 sayılı Çevre Kanunu hükümlerinin katı ve tavizsiz şekilde uygulanması gerekmektedir.

Yerel, doğal ve beşeri koşulların baskın ve zorlayıcı etkisiyle hayvancılık ve tarım faaliyetlerinin ön plana çıktığı ilde ekonomik gelişim hızının düşük olmasına rağmen projeksiyone edilen 2040 yılı için genel arazi sınıflarının alanlarında önemli oranda değişim beklenmektedir. Kars ilinde 2040 yılında, arazi örtüsünün; \%2,1'inin "1" ana kodlu Yapay Yüzeyler sınıfında, \%60,9'unun " 2 " ana kodlu Tarım Alanları sinıfinda, \%35,9'unun "3" ana kodlu Orman ve Yarı Doğal alanları sınıfında, $\% 0,16$ 'sının " 4 " ana kodlu Islak alan sinıfinda \%0,9'unun ise "5" ana kodlu Su Toplulukları sinıfindaki arazilerden oluşabileceği projeksiyone edilmiştir.

Hakem Değerlendirmesi: Dış bağımsız.

Çıkar Çatışması: Yazarlar çıkar çatışması bildirmemiştir.

Finansal Destek: Yazarlar bu çalışma için finansal destek almadığını beyan etmiştir.

Peer-review: Externally peer-reviewed.

Conflict of Interest: The authors have no conflict of interest to declare.

Grant Support: The authors declared that this study has received no financial support.

\section{KAYNAKÇA/REFERENCES}

Atalay, İ. (2008). Ekosistem Ekolojisi ve Coğrafyası. Çevre ve Orman Bakanlığı Yayınları. İzmir.

Atalay, İ., \& Mortan, K. (2003). Türkiye Bölgeler Coğrafyası (İkinci bask1). İnk1lâp Kitabevi, İstanbul.

Clark Labs, (2018). About Clark Labs. https://clarklabs.org/ adresinden 6 Mart 2020 tarihinde edinilmiştir.

Comber, A., Fisher, P., \& Wadsworth, R. (2005). What is land cover?. Environment and Planning B: Planning and Design, 32(2), 199209.

COPERNICUS, CORINE (1990). https://land.copernicus. eu/paneuropean/CORINE-land-cover adresinden 18 Nisan 2020 tarihinde edinilmiştir.

COPERNICUS, CORINE (2018). https://land.copernicus. eu/paneuropean/CORINE-land-cover, adresinden 15 Nisan 2020 tarihinde edinilmiştir.

Çivi, A., Akgündüz, E., Kalaycı, K., İnan, Ç., Sarıca, E., \& Toru, E. (2009). CORINE (Coordination of Information on the Environment) projesi. TMMOB Coğrafi Bilgi Sistemleri Kongresi, 200, 02-06.

Demir, M., (2013). Kars Kent Coğrafyas1. Atatürk Üniversitesi Sosyal Bilimler Enstitüsü (Yayımlanmamış Doktora Tezi), Erzurum,

Demir, M. (2016). Kars İlinde Büyük ve Küçükbaş Hayvancılık. Eastern Geographical Review, 20(35).
Demir, M. (2015). Kars İlinin Nüfus Gelişimi Ve Başlıca Demografik Özellikleri. Doğu Coğrafya Dergisi, 20(34), 127-156.

Demir, M. (2018). Doğal ve Beşeri Çevre Özellikleri Bakımından Kağızman İlçe Merkezi. Pegem Akademi. Ankara.

DMİGM (2016). Ankara: Devlet Meteoroloji İşleri Genel Müdürlüğü.

Dzieszko, P. (2014). Land-cover modelling using corine land cover data and multi-layer perceptron. Quaestiones Geographicae, 33(1), 5-22.

Eastman, J. R. (2009). IDRISI Guide to GIS and Image Processing Accessed in IDRISI Selva 17. Clark University, Worcester, 182185.

Eastman J. R. (2012). IDRISI Guide to GIS and Image Processing Accessed in IDRISI Selva 17. Clark University, Worcester, 324 p.

European Environment Agency. (2020). https://www.eea.europa.eu/ İnternet adresinden 10 Nisan 2020 tarihinde edinilmiştir.

Fisher, P. F., Comber, A. J., \& Wadsworth, R. (2005). Land use and land cover: contradiction or complement. Re-presenting GIS, 85-98.

HGK. (2014). www.hgk.msb.gov.tr/images/urun/il_ilce_alanlari.pdf, adresinden 10.Nisan.2020 tarihinde edinilmiştir.

MTA. (2008). Kars İli Genel Jeolojisi, Doğu Anadolu Bölge Müdürlüğü, Van

Ott, L., Larson R. F., Mendenhall, W. (1983). Statistics: A Tool for the Social Sciences. Boston: Duxbury Press.

Pontius, G. R. (2000). Quantification error versus location error in comparison of categorical maps. Photogrammetric Engineering, Remote Sensing, 66(8), 1011-1016.

Pontius, G. R., \& Malanson, J. (2005). Comparison of the structure and accuracy of two land change models. International Journal of Geographical Information Science, 19(2), 243-265.

Rumelhart D., Hinton G., Williams R. (1986). Learning internal representations by error propagation. In: D.E. Rumelhart, J.L. McClelland (eds), Parallel distributed processing: explorations in the microstructures of cognition (Vol. 1; pp. 318-362). Cambridge: MIT Press

Sang, L., Zhang, C., Yang, J., Zhu, D., \& Yun, W. (2011). Simulation of land use spatial pattern of towns and villages based on CA-Markov model. Mathematical and Computer Modelling, 54(3-4), 938-943.

Subedi, P., Subedi, K., \& Thapa, B. (2013). Application of a hybrid cellular automaton-Markov (CA-Markov) model in land-use change prediction: a case study of Saddle Creek Drainage Basin, Florida. Applied Ecology and Environmental Sciences, 1(6), 126132.

TUIK. (2021). https://data.tuik.gov.tr/Kategori/GetKategori?p=Nufusve-Demografi-109 adresinden 10 Şubat 2017 tarihinde edinilmiştir.

Tarım ve Orman Bakanlığı. (2020). https://CORINE.tarimorman.gov.tr/ CORINEportal/amac.html adresinden 10 Nisan 2020 tarihinde edinilmiştir.

Turner, B. L., \& Meyer, W. B. (1994). Global land-use and land-cover change: an overview. Changes in land use and land cover: a global perspective, 4(3). 